NBER WORKING PAPER SERIES

POST-SECONDARY ATTENDANCE BY PARENTAL INCOME IN THE U.S. AND CANADA: WHAT ROLE FOR FINANCIAL AID POLICY?

\author{
Philippe Belley \\ Marc Frenette \\ Lance Lochner \\ Working Paper 17218 \\ http://www.nber.org/papers/w17218 \\ NATIONAL BUREAU OF ECONOMIC RESEARCH \\ 1050 Massachusetts Avenue \\ Cambridge, MA 02138 \\ July 2011
}

The views expressed herein are those of the authors and do not necessarily reflect the views of the National Bureau of Economic Research. Lochner acknowledges research support from the Social Sciences and Humanities Research Council of Canada. The views expressed herein are those of the authors and do not necessarily reflect the views of the National Bureau of Economic Research.

NBER working papers are circulated for discussion and comment purposes. They have not been peerreviewed or been subject to the review by the NBER Board of Directors that accompanies official NBER publications.

(C) 2011 by Philippe Belley, Marc Frenette, and Lance Lochner. All rights reserved. Short sections of text, not to exceed two paragraphs, may be quoted without explicit permission provided that full credit, including $\odot$ notice, is given to the source. 
Post-Secondary Attendance by Parental Income in the U.S. and Canada: What Role for Financial Aid Policy?

Philippe Belley, Marc Frenette, and Lance Lochner

NBER Working Paper No. 17218

July 2011

JEL No. H52,I21,I28

\begin{abstract}
$\underline{\text { ABSTRACT }}$
This paper examines the implications of tuition and need-based financial aid policies for family income - post-secondary (PS) attendance relationships. We first conduct a parallel empirical analysis of the effects of parental income on PS attendance for recent high school cohorts in both the U.S. and Canada using data from the 1997 Cohort of the National Longitudinal Survey of Youth and Youth in Transition Survey. We estimate substantially smaller PS attendance gaps by parental income in Canada relative to the U.S., even after controlling for family background, adolescent cognitive achievement, and local residence fixed effects. We next document that U.S. public tuition and financial aid policies are actually more generous to low-income youth than are Canadian policies. By contrast, Canada offers more generous aid to middle-class youth than does the U.S. These findings suggest that the much stronger family income - PS attendance relationship in the U.S. is not driven by differences in the need-based nature of financial aid policies. Based on previous estimates of the effects of tuition and aid on PS attendance, we consider how much stronger income - attendance relationships would be in the absence of need-based aid and how much additional aid would need to be offered to lower income families to eliminate existing income - attendance gaps entirely.
\end{abstract}

Philippe Belley

Kansas State University

Economics

339A Waters Hall

Manhattan, KS 66506-4001

U.S.A.

pbelley@k-state.edu

Marc Frenette

Social Research \& Demonstration Corporation

55 Murray Street Suite 400

Ottawa, Ontario

mfrenette@srdc.org
Lance Lochner

Department of Economics

Faculty of Social Science

University of Western Ontario

1151 Richmond Street, North

London, ON N6A 5C2

CANADA

and NBER

1lochner@uwo.ca

An online appendix is available at:

http://www.nber.org/data-appendix/w17218 


\title{
Post-Secondary Attendance by Parental Income in the U.S. and Canada: What Role for Financial Aid Policy?*
}

\author{
Philippe Belley \\ Kansas State University
}

\author{
Marc Frenette \\ Social Research \& \\ Demonstration Corporation
}

June 13, 2011

\author{
Lance Lochner \\ University of Western Ontario
}

\begin{abstract}
This paper examines the implications of tuition and need-based financial aid policies for family income - post-secondary (PS) attendance relationships. We first conduct a parallel empirical analysis of the effects of parental income on PS attendance for recent high school cohorts in both the U.S. and Canada using data from the 1997 Cohort of the National Longitudinal Survey of Youth and Youth in Transition Survey. We estimate substantially smaller PS attendance gaps by parental income in Canada relative to the U.S., even after controlling for family background, adolescent cognitive achievement, and local residence fixed effects. We next document that U.S. public tuition and financial aid policies are actually more generous to low-income youth than are Canadian policies. By contrast, Canada offers more generous aid to middle-class youth than does the U.S. These findings suggest that the much stronger family income - PS attendance relationship in the U.S. is not driven by differences in the need-based nature of financial aid policies. Based on previous estimates of the effects of tuition and aid on PS attendance, we consider how much stronger income - attendance relationships would be in the absence of need-based aid and how much additional aid would need to be offered to lower income families to eliminate existing income - attendance gaps entirely.
\end{abstract}

\section{Introduction}

The relationship between family income and educational attainment is of broad interest for both equity and efficiency reasons. Clearly, the failure of youth from low-income families to acquire a good education limits economic and social mobility. The implications for social efficiency are more complicated. On the one hand, if borrowing constraints or other barriers (e.g. a lack of information) discourage or prevent economically disadvantaged youth from attending post-secondary institutions, then outcomes are likely to be inefficient as well as inequitable. On the other hand, if low-income youth

${ }^{*}$ We thank Leesha Lin for her help in providing various CSLP statistics and Enrico Moretti and Janet Currie for providing us with their data on U.S. colleges and universities by county. For their comments and advice, we thank Barbara Glover, David Johnson, Steve Machin, Arthur Sweetman, Alex Usher, conference participants at the NLSY97 Tenth Anniversary Conference, 2009 RCEA Summer Labor Economics Workshop, 2008 and 2010 Canadian Economics Association Annual Meetings, 2008 MESA Workshop, CESifo Workshop on the Economics of Education, 2011 NBER Spring Labor Meeting, and seminar participants at Boston College, Brown University, McMaster University, NYU, Pennsylvania State University, University of Illinois, University of Montreal, University of Pittsburgh, and Virginia Tech. 
do not attend college or university, because they are ill-qualified or dislike school, then education gaps by income need not be inefficient. These competing explanations have led to spirited debate among economists as to the underlying causes for observed family income - schooling attainment gaps (see, e.g., Carneiro and Heckman 2002, 2003, Krueger 2003).

Citing both equity and efficiency reasons, most governments heavily subsidize higher education with the explicit aim of increasing access. In many countries, tuition at post-secondary (PS) institutions is negligible. In the U.S. and Canada - our focus in this paper - annual tuition at public schools typically ranges from $\$ 3$-10 thousand; however, both countries offer considerable financial aid to those in need. In many American states, the direct cost of a higher education (net of non-repayable financial aid) is negative for youth at the bottom of the income distribution. ${ }^{1}$ More generally, the net price of PS education is increasing in family income in both Canada and the U.S. Given the substantial resources devoted to financial aid, it is important to ask whether and how these resources affect PS access and attendance patterns by family income.

Numerous studies estimate the effects of tuition and specific financial aid programs on PS attendance and completion rates. As recently surveyed by Kane (2006) and Deming and Dynarski (2009), most conclude that lowering the annual price of PS schooling (either through reductions in tuition or increases in non-repayable aid) by $\$ 1,000$ leads to a 3-5 percentage point increase in PS attendance. Based on these findings, one would expect the overall structure of need-based financial aid to play an important role in shaping the relationship between family income and PS attendance; yet, this issue is rarely discussed in the literatures on family income - PS attendance gaps or intergenerational mobility. Indeed, one is hard-pressed to find a full accounting of financial aid and tuition costs as they relate to family income (in either Canada or the U.S.). We take on this task and explore the extent to which important differences in the overall structure of aid contribute to or ameliorate Canada - U.S. differences in family income - PS attendance patterns.

Using U.S. data from the 1997 Cohort of the National Longitudinal Survey of Youth (NLSY97) and Canadian data from the Youth in Transition Survey (YITS), we first document a much stronger (unconditional) relationship between parental income and PS attendance in the U.S. relative to Canada. Although more than half of this difference disappears after controlling for family background, local area of residence fixed effects, and adolescent cognitive achievement, the remaining difference is still substantial. Conditional on these factors, PS attendance rates are roughly 18 percentage points higher for American youth in the top parental income quartile relative to those in the bottom quartiles. The

\footnotetext{
${ }^{1}$ As discussed in greater detail below, this reflects tuition net of grants, scholarships, and family tax credits. Of course, the total cost of PS schooling may be positive due to opportunity costs associated with foregone earnings while in school.
} 
same income - attendance gap is only 7 percentage points in Canada. The cross-country difference is largely attributed to relatively low attendance rates by low-income American youth from all ability backgrounds.

It is tempting to blame the stronger U.S. income - attendance gap on its higher average tuition levels: average annual tuition at four-year public institutions was nearly $40 \%$ higher in the U.S. than it was in Canada in 2003-04. ${ }^{2}$ Yet, this ignores any differences in financial aid policies between the two countries. To examine the importance of these differences, we document the overall structure of tuition and financial aid in both countries. In particular, we calculate measures of annual net tuition (tuition less all non-repayable aid) and out-of-pocket expenditures (net tuition less available government loan amounts) for public four-year institutions as functions of parental income. Perhaps surprisingly, we show that, on average, the U.S. is considerably more generous (than Canada) in offering aid to the most economically disadvantaged, while Canada is slightly more generous (than the U.S.) towards middle-income youth. ${ }^{3}$ In contrast to our empirical findings from the NLSY97 and YITS, these net tuition and out-of-pocket expenditure schedules predict a weaker parental income - PS attendance relationship in the U.S.

The contrast between net tuition schedules and attendance patterns is stark and puzzling. For example, we show that American youth whose parents earn $\$ 25,000$ pay roughly $\$ 4,000$ less in net tuition than their better-off counterparts whose parents earn $\$ 75,000$. In Canada, the same low-income youth pay roughly $\$ 2,500$ less, on average, than their wealthier counterparts. All else equal, these net tuition differences suggest attendance rates should be 12-20 percentage points higher for low-income Americans and 8-13 percentage points higher for low-income Canadians relative to their higher income counterparts. ${ }^{4}$ Of course, all else is not equal, and other factors may generate a positive relationship between schooling and parental income (e.g. credit constraints may affect youth from low-income families, tastes for schooling may be positively related to family income). What is more surprising is the much stronger positive relationship in the U.S. given its greater targeting of student aid to the most disadvantaged. Accounting for differences in aid, low-income Americans pay a few thousand dollars less than their Canadian counterparts; yet, they attend colleges and universities at much lower rates. To better understand why, we empirically examine and discuss a number of factors (in addition

\footnotetext{
${ }^{2}$ This comparison reflects differences in the purchasing power parity (PPP) index. Average Canadian tuition was $\$ 4,025$ in Canadian dollars, while average U.S. tuition was $\$ 4,645$ in U.S. dollars. Adjusting for PPP (1.20 in 2004$)$, average U.S. tuition was $\$ 5,574$ in Canadian dollars.

${ }^{3}$ Quebec is an exception within Canada. Net tuition in Quebec is similar to that in low-tuition American states; however, out-of-pocket expenditures are generally higher at all parental income levels than low- or high-tuition American states.

${ }^{4}$ These are based on typical estimates of the impact of tuition and aid on attendance ranging from 3 to 5 percentage points per $\$ 1,000$ (see Kane 2006 or Deming and Dynarski 2009).
} 
to financial aid policies) that may shape the family income - PS attendance relationship.

Even if PS costs are not the main determinant of family income - attendance differences, financial aid policies may help eliminate them. Indeed, the need-based nature of aid already serves to reduce differences in PS attendance by income. Using standard estimates of the effect of tuition and aid on attendance, we consider a number of 'back-of-the-envelope' calculations that help shed light on the current and potential role of financial aid policies. We first consider how much larger American and Canadian family income - PS attendance gaps would be in the absence of need-based aid programs. We then consider how much more grant aid would need to be given to low-income families in the U.S. and Canada to completely eliminate their income - attendance gaps (conditional on adolescent achievement and family background). These admittedly rough calculations highlight two important points: (i) there are sizeable differences in underlying demand for PS education by family income (even at below-cost tuition levels), and (ii) it would be quite costly to eliminate those differences entirely by simply expanding current need-based policies.

This paper proceeds as follows. The next section briefly reviews the related literatures on family income - PS attendance gaps and on the effects of tuition and financial aid on PS schooling. We describe the YITS and NLSY97 data in Section 3, presenting evidence on PS attendance by parental income in Section 4. Section 5 documents PS costs and financial aid policies in Canada and the U.S., focusing on the dependence of net tuition and out-of-pocket expenditures on parental income. Section 6 considers the implications of Canada and U.S. financial aid policies for family income - PS attendance relationships. We present a few counterfactual calculations that clarify the extent to which need-based aid can and does influence income - attendance gaps. Section 7 concludes.

\section{Related Literature}

\subsection{Post-Secondary Attendance Differences by Family Income}

There is a strong correlation between measured cognitive ability and family income. As such, most researchers examining the relationship between family income and schooling attempt to simultaneously control for adolescent achievement and other family background characteristics that might affect schooling. Doing so substantially reduces the role of family income in most studies but does not generally eliminate it.

Studies using U.S. data from the 1979 Cohort of the National Longitudinal Survey of Youth (NLSY79) generally conclude that family income played little role in PS attendance decisions in the 
U.S. during the early 1980s. ${ }^{5}$ Cameron and Heckman $(1998,2001)$ find that after controlling for family background, scores on the Armed Forces Qualifying Test (AFQT), and unobserved heterogeneity, family income has little effect on PS enrollment rates. ${ }^{6}$ Carneiro and Heckman (2002) also estimate small differences in PS enrollment rates and other higher education outcomes by family income after accounting for differences in family background and AFQT. Related work by Cameron and Taber (2004) and Keane and Wolpin (2001) suggests that borrowing constraints had little effect on educational attainment for the NLSY79 cohort.

Belley and Lochner (2007) and Lochner and Monge-Naranjo (2010) argue that the rising costs of and returns to PS education in the U.S. since the early 1980s, combined with relatively stable real government student loan limits, have likely increased the salience of borrowing constraints for American youth. ${ }^{7}$ Consistent with this hypothesis, Belley and Lochner (2007) estimate that the effects of family income on PS attendance (conditional on family background and AFQT scores) roughly doubled between the early 1980s and 2000s (based on data from the NLSY79 and NLSY97, respectively). Elwood and Kane (2000) also document an increasing role of family income over the 1980 s. $^{8}$

In Canada, a lack of appropriate data has limited serious examination of the issue until very recently. Frenette (2007) examines the gap in attendance at four-year PS institutions between youth from families in the top and the bottom quartiles of family income. Using a Blinder-Oaxaca decomposition, he finds that $84 \%$ of the total gap in attendance between youth from the top and bottom income quartiles can be accounted for by long-term ability and family differences like age 15 achievement and grades, parental influences, and high school quality. ${ }^{9}$

Differences in approach and specifications across previous U.S. and Canadian studies make crosscountry comparisons of the relationship between family income and PS attendance difficult. This

\footnotetext{
${ }^{5}$ Manski and Wise (1983) document the importance of family income for schooling in the U.S. for earlier cohorts.

${ }^{6} \mathrm{AFQT}$ test scores are widely used as a measure of cognitive achievement by social scientists using the NLSY79 or NLSY97 data. They are strongly correlated with positive outcomes like education and post-school earnings. See, e.g., Blackburn and Neumark (1993), Murnane, Willett, and Levy (1995), and Cawley, et al. (2000). We discuss the composition of this test further below.

${ }^{7}$ Indeed, the fraction of undergraduate borrowers that borrowed the maximum limit from the federal Stafford Student Loan Program nearly tripled to 52\% between 1990 and 2000 (Berkner 2000 and Titus 2002). See Heckman, Lochner, and Todd (2008) for evidence on rising returns to school and College Board (2004) for evidence on rising tuition costs.

${ }^{8}$ Two other U.S.-based studies are related. Lovenheim (2011) exploits variation in local housing markets to identify the effects of changes in family wealth on PS enrolment decisions. He estimates significant effects of wealth for youth from lower-income families and finds that wealth has become a more important determinant of PS enrolment in recent years. Brown, Scholz and Seshadri (2011) estimate significant effects of financial aid on schooling attainment among 'borrowing constrained' youth using intergenerational data from the Health and Retirement Survey. Roughly half of their sample (covering the 1970s, 1980s, and 1990s) is borrowing constrained by their definition.

${ }^{9}$ Christofides, Cirello, and Hoy (2001) and Corak, Lipps, and Zhao (2003) also examine post-secondary attendance patterns in Canada, while Frenette (2005) examines differences in PS attendance rates by parental income in the U.S. and Canada. None of these studies account for the important role of adolescent achievement.
} 
paper carefully explores this relationship for Canadian and American youth from roughly the same age cohort using similar measures of family background, parental income, and adolescent cognitive achievement.

\subsection{Effects of Tuition and Financial Aid on Post-Secondary Attendance}

A large literature studies the demand for higher education by estimating the effects of tuition and financial aid on PS attendance. Kane (2006) and Deming and Dynarski (2009) provide recent surveys of this literature, so we limit our discussion to a few key findings relevant to our analysis.

Summarizing earlier studies, Leslie and Brinkman $(1987,1988)$ conclude that a $\$ 1,000$ (in year 2003 U.S.\$) reduction in PS costs leads to a roughly 3-5 percentage point increase in PS attendance rates in the U.S. Most recent estimates on the effects of tuition on PS attendance using cross-state variation or variation within states over time fall roughly within this 'consensus' range as well (e.g. Kane 1994, 1999, Cameron and Heckman 2001). ${ }^{10}$

Numerous studies estimate the effects of student grant/scholarship aid on enrolment as well. Examining the introduction of Pell Grants in the mid-1970s, Hansen (1983) and Kane (1994) estimate small impacts on PS enrolment rates among low-income American youth. Kane (1994) also estimates separate effects of changes in tuition and estimated Pell Grant aid eligibility amounts on PS enrolment over the 1970s and 1980s. These estimates generally suggest modest but relatively weaker effects of Pell Grant aid compared to the effects of tuition. ${ }^{11}$

Recent studies have explored the enrolment impacts of more targeted student aid programs. Estimated impacts of aid from these studies are generally in line with the 'consensus' estimates of the impact of tuition changes on enrolment (3-5 percentage point enrolment changes per $\$ 1,000)$. For example, Dynarski (2003) studies the elimination of the Social Security student benefit program in the early 1980s, which provided income transfers to 18-22 year-old children of deceased, disabled or retired Social Security beneficiaries as long as they remained enrolled full-time in PS school. Her estimates suggest that an additional $\$ 1,000$ in student aid would increase PS attendance by about four percentage points. Dynarski (2000) estimates that an extra $\$ 1,000$ in non-repayable aid from the Georgia HOPE scholarship program increased PS attendance by 4-6 percentage points among af-

\footnotetext{
${ }^{10}$ A few early studies (e.g. Bishop (1977), Manski and Wise (1983), McPherson and Schapiro (1991)) estimate relatively larger tuition impacts on enrolment among youth from lower income families. More recent studies (e.g. Elwood and Kane 2000, Cameron and Heckman 2001) provide mixed evidence on this point. Our calculations below assume similar responses across the income distribution.

${ }^{11}$ Seftor and Turner (2002) estimate sizeable effects of changes in Pell Grant amounts/eligibility on enrolment among 'older' individuals in their late 20 s and 30 s.
} 
fected Georgians. ${ }^{12}$ Abraham and Clark (2006) and Kane (2007) estimate effects of similar magnitude for the broad-based Washington DC Tuition Assistance Grant program introduced in 2000-01, while Kane (2003) estimates significant enrolment impacts of the recent CalGrant program for low-income California students with good high school grades. Altogether, these studies suggest that financial aid significantly increases PS attendance for a wide range of American subpopulations.

Fortin (2005) examines the impacts of PS costs in Canada and the U.S. over the 1970s, 1980s, and 1990s. Her estimates imply similar enrolment impacts of tuition for both countries over this period (roughly 4 percentage point increase per $\$ 1,000$ tuition reduction). Her estimates also suggest that increases in student aid have more modest effects (for Canada).

Our analysis below considers the role of need-based financial aid policies on PS attendance patterns. We are, therefore, primarily interested in the extent to which changes in current amounts of student aid might impact PS attendance. While evidence from tuition variation (across states/provinces or within states/provinces over time) and recent state aid programs consistently predicts impacts of 3-5 percentage points per $\$ 1,000$, earlier studies estimate weaker effects associated with the introduction of federal Pell grants. Some have suggested that the weaker impacts of Pell Grants may be the result of complex federal aid application procedures and a lack of information about aid eligibility or amounts. ${ }^{13}$ These problems are likely to have been most severe at the introduction of Pell Grants in the mid-1970s, thereby limiting the initial aid impacts estimated by Hansen (1983) and Kane (1994). Today, most low-income youth interested in attending an American PS institution would fill out federal financial aid forms whether or not they receive any state-specific grant or scholarship, so potential new students face this application burden regardless of the source of new aid. For example, Kane (2007) estimates sizeable impacts of the DC Tuition Assistant Grant Program on the number of FAFSA filers and Pell Grant recipients from Washington DC that are similar in magnitude to effects on enrolment. Furthermore, Kane's (2003) estimated impacts of the CalGrant program on PS enrollment are based on a sample of California residents who had applied for federal aid. Both of these studies suggest that recent financial aid programs encourage PS enrolment despite any federal aid application burdens. However discouraging the federal aid application process may be, the impacts of changing current financial aid policies are likely to be similar regardless of the source of aid. ${ }^{14}$ The consistency of recent

\footnotetext{
${ }^{12}$ Cornwell, Mustard, and Sridhar (2006) also estimate significant effects of the Georgia HOPE scholarship on enrolment rates in Georgia PS institutions.

${ }^{13}$ As noted by Kane (1994), Pell Grant eligibility is also likely to be measured with error, biasing estimated effects toward zero in these studies.

${ }^{14}$ This does not mean financial aid forms are not a burden or that aid would not be more effective at encouraging PS attendance in the absence of complicated forms. Indeed, recent estimates by Bettinger, et al. (2009) suggest that the burden imposed by federal aid forms may be quite discouraging.
} 
financial aid and tuition impacts on enrolment suggest that the relatively small impacts associated with the introduction of Pell Grants in the mid-1970s are unlikely to be very informative about the impacts of changes in financial aid policies today.

Given the body of evidence, especially from more recent studies, our calculations below assume estimated PS attendance responses of 3-5 percentage points per $\$ 1,000$ in net tuition. Even these estimates may be conservative, since changes in tuition or the amount of aid offered from any one source are often offset by changes in other sources of aid (e.g. institutional support). For example, we show below that differences in tuition between high- and low-tuition American states are partially offset, especially among low-income youth, by adjustments in institutional and state aid. This would tend to bias estimated tuition effects towards zero.

\section{$3 \quad$ NLSY97 and YITS Data}

Our main empirical analysis uses data from the NLSY97 and YITS, focusing on educational attainment as of age 21. The NLSY97 samples American youth ages 12-16 at the beginning of 1997, while YITS surveys Canadian youth age 15 at the start of $2000 .{ }^{15}$ Youth in both samples made their PS attendance decisions in the early to mid-2000s. Most importantly, NSLY97 and YITS contain comparable measures of adolescent cognitive achievement, parental income during adolescence, and rich measures of family background.

In 1997, NLSY97 respondents took a large battery of tests known as the Armed Forces Vocational Aptitude Battery (ASVAB). ${ }^{16}$ In 2000, YITS respondents took math, reading, and science tests from the Programme for International Student Assessment (PISA). All respondents took the reading assessment, but only half the respondents took the math assessment while the other half (both randomly assigned) took the science assessment. We focus on the half taking both the reading and mathematics assessments. Our analysis uses a combined math-reading achievement measure, which is simply the average of normalized math and reading assessment scores. For comparability in the NLSY97, we create a combined math-reading achievement measure from four ASVAB assessments (arithmetic reasoning, mathematics knowledge, paragraph comprehension, and word knowledge). Finally, we categorize individuals according to their normalized test score quartiles. ${ }^{17}$

\footnotetext{
${ }^{15}$ In the NLSY97, we exclude youths that are part of the minority and poor white over-samples, using only the full random samples in our analysis.

${ }^{16}$ Four ASVAB subtests are combined to create the AFQT scores discussed earlier. The full set of subtests includes arithmetic reasoning, assembling objects, auto information, coding speed, electronics information, general science, mathematics knowledge, mechanical comprehension, numerical operations, paragraph comprehension, shop information, and word knowledge.

${ }^{17}$ For both data sources, we first normalize individual test scores by subtracting the mean score and dividing by its
} 
The NLSY97 measures income for all household members (received in 1996), while YITS only contains measures of parental income (received in 1999). For comparability, we use total parental income (excluding income from other household or family members) in both samples for our analysis. ${ }^{18}$ Parental income is measured when youth are age 15 in YITS and ages 12-16 in the NLSY97; however, this discrepancy does not play an important role in our findings. We denominate income in year 1999 dollars, using the U.S. Consumer Price Index for all urban consumers (CPI-U) to adjust for inflation in the NLSY97. We also consider income adjustments to account for differences in the Canada-U.S. currency exchange rate or the purchasing power parity (PPP) index. ${ }^{19}$

Our analysis focuses primarily on PS attendance as of age $21 .^{20}$ Individuals in the NLSY97 are considered to have attended a PS institution if they attended at least 13 years of regular school. This includes traditional two- and four-year colleges and universities but would generally exclude participation in shorter training or vocational programs. In YITS, our measure of PS attendance is based on reported attendance by age 21 in a qualifying PS program or institution, including 'colleges' (twoyear institutions), 'universities' (four-year institutions), or Quebec's CEGEP ('College d'enseignement general et professionnel', meaning College of General and Vocational Education) program. Consistent with our NLSY97 measure, we exclude participation in shorter vocational, training, licensing, or apprenticeship programs. In some cases, we also consider whether youth ever reported attending a four-year PS institution by age 21 .

Our multivariate analysis controls for a rich set of family background measures. We control for maternal education by categorizing mothers as high school dropouts, those who completed high school or more, and those who completed at least one year of PS schooling. We also account for family structure by controlling for the number of household members under the age of 18 as of the first survey date. Additional family structure information is provided by an indicator variable for whether both biological parents are present in the home at the time of the initial survey. We include controls for whether the youth is an immigrant and whether at least one parent is an immigrant. We account

standard deviation. This generates normalized scores for all tests with a mean of zero and standard deviation of one. In the NLSY97, we normalize within each age group (in years). In YITS, our math-reading achievement measure is the simple average of the normalized math and reading scores. In the NLSY97, we first create a math (reading) score by taking an average of normalized scores for arithmetic reasoning and mathematics knowledge (paragraph comprehension and word knowledge). We normalize these scores and then take their average as our math-reading achievement measure — its correlation with AFQT percentile is over 0.97 in our sample.

${ }^{18}$ The correlation between total parental income and total household income (used by Belley and Lochner (2007)) is 0.96 in the NLSY97.

${ }^{19}$ In 1999, the average nominal exchange rate was 1.49 while the PPP was 1.19 . That is, the U.S. dollar was worth 1.49 (or 1.19 using PPP) Canadian dollars.

${ }^{20}$ Schooling attainment at age 22 is used in the NLSY97 if it is missing or unavailable at age 21 (fewer than $10 \%$ of all respondents). 
for family residence in a metropolitan area at age $15 .{ }^{21}$ We control for the mother's age at the time of the respondent's birth as well as gender in both surveys. Finally, we control for race (blacks, hispanics, other non-whites, and whites) and year of birth in the NLSY97.

Descriptive statistics for these variables are provided in Table 1 for both surveys. ${ }^{22}$ Comparisons across samples suggest that schooling attainment is higher in Canada, except at the top end. Both high school and PS attendance rates are about 10\% higher in Canada than the U.S. (93\% vs. $83 \%$ for PS attendance and $71 \%$ vs. $63 \%$ for high school completion). ${ }^{23}$ By contrast, $42 \%$ of youth attended a 4-year PS school in both countries. Educational attainment is also higher among Canadian mothers. Compared to American youth, Canadian youth are less likely to be non-white, but more likely to be first- or second-generation immigrants. ${ }^{24}$ Canadian youth also tend to have slightly older mothers and are more likely to have both biological parents present in the household during adolescence. Fewer Canadian youth grow up in metropolitan areas.

Table 1 also reports average parental income and average income within each of the four quartiles for Canada and the U.S. (denominated in year 1999 dollars). For comparability, the table shows U.S. income levels after adjusting for differences in PPP. After adjusting for PPP, American parents average about $\$ 7,500$ less in income than Canadian parents each year. ${ }^{25}$ Income is more dispersed in the U.S. Most notably, parents in the lowest income quartile in the U.S. report annual income averaging $\$ 15,600$ while Canadian parents in the bottom quartile reported incomes averaging $\$ 28,100$. In the top quartile, American and Canadian parental incomes differ by less than $\$ 1,000$, both averaging around $\$ 125,000$.

Finally, we note that parental income and achievement are strongly correlated in both samples. Roughly $35 \%$ of American youth are in the same achievement and family income quartiles, compared to $30 \%$ of Canadian youth. ${ }^{26}$

\footnotetext{
${ }^{21}$ In the NLSY97, 'metropolitan residence' reflects residence in a U.S. Metropolitan Statistical Area (MSA) at age 15 if available; otherwise, we use residence at age 16 (or 17 if also unavailable at 16). An analogous Canadian measure was created for YITS using an indicator for whether the respondent's Census Metropolitan Area (CMA) or Census Agglomeration Area (CA) had a population of greater than 50,000.

${ }^{22}$ These samples are restricted to individuals for whom we observe both math-reading scores and parental income.

${ }^{23}$ In the NLSY97, respondents are assumed to have completed high school if they completed 12 or more years of school by age 21 . In YITS, high school completion is self-reported as of age 21 .

${ }^{24}$ In the U.S., hispanic and African Americans are both sizeable minorities, each representing 10-15\% of the population. Asians represent fewer than $5 \%$. In Canada, blacks and hispanics make up less than $1 \%$ of the population, while Asians represent nearly $10 \%$ of the population. In 2001, $18 \%$ of all Canadians were foreign-born, roughly $40 \%$ of them immigrating from Europe and another third from Asia. By comparison, 11\% of the U.S. population in 2000 was foreignborn, with about half immigrating from Latin America and one-quarter from Asia. Finally, Canada differs in that it contains a sizeable francophone population with about one-fifth of the population speaking French at home. The vast majority of Canadian francophones live in Quebec.

${ }^{25}$ Using the (higher) official currency exchange rate, average parental income in the U.S. $(\$ 80,000)$ was almost $\$ 9,000$ higher than in Canada.

${ }^{26}$ See Belley, Frenette, and Lochner (2010) for the joint distribution of parental income and achievement in the NLSY97
} 


\section{Achievement, Parental Income and Educational Attainment}

Figure 1 reports PS attendance rates by parental income quartile in Canada and the U.S. Education and parental income are positively correlated in both countries, but the correlation is substantially stronger in the U.S. Canadian youth with parents in the highest income quartile are nearly twenty percentage points more likely to attend a PS institution than are youth from the lowest income quartile. In the U.S., this difference is about 45 percentage points. High income youth from both countries have similar PS attendance rates, but low income youth in the U.S. have much worse educational outcomes than their Canadian counterparts.

Figure 2 shows PS attendance rates by parental income and math-reading achievement quartiles in YITS and the NLSY97. Not surprisingly, math and reading skills play an important role in determining educational attainment. Both achievement and parental income are more important determinants of PS attendance in the U.S. than in Canada. In Canada, income has much greater effects on PS attendance for the least able than for all other math-reading achievement quartiles. Among the least able, youth from the highest income quartile appear to be outliers with attendance rates that are 13-20 percentage points higher than all other income groups. Other achievement groups show an attendance gap of 8-12 percentage points between the highest and lowest income quartiles. The picture for the U.S. is quite different. In the NLSY97 data, differences in attendance between the highest and lowest income quartiles range from 20-30 percentage points for all achievement groups.

To further explore these relationships, we employ a similar methodology to that used in Ellwood and Kane (2000), Carneiro and Heckman (2002) and Belley and Lochner (2007), who analyze the effects of family income and achievement on schooling decisions in the U.S. after controlling for other family background characteristics. Since we are mainly interested in how parental income - educational attainment relationships compare between Canada and the U.S., we employ very similar estimation specifications for both YITS and the NLSY97. Specifically, we regress educational outcomes on parental income quartiles during the respondent's late teenage years, math-reading achievement quartiles, and nearly identical family background measures (as discussed earlier). We primarily use parental income and achievement quartiles to allow for non-linear relationships; however, we consider alternative assumptions about the role of parental income below.

Table 2 reports estimates of our main specifications for the YITS and NLSY97 data. First, consider the determinants of PS attendance in Canada and the U.S. reported in the first two columns. There is general agreement between both countries regarding the role played by family background. and YITS. 
Immigration status (of the youth and his or her parents) and maternal education have fairly strong positive effects on PS attendance rates in both countries. Youth born to older mothers, youth living in metropolitan areas, and youth living in intact families (both biological parents present) during adolescence are more likely to have attended a PS institution by age 21. The magnitudes of these effects are modest and similar across the two countries. As observed in Figure 2, math-reading achievement and parental income are both substantially more important determinants of PS attendance in the U.S. compared to Canada. ${ }^{27}$ In Canada, the most able are 37 percentage points more likely to attend college relative to the least able; this gap is more than 50 percentage points in the U.S. The difference in attendance rates between the highest and lowest income quartiles is about 7 percentage points in Canada and about 18 percentage points in the U.S. ${ }^{28}$ While this difference is less than half the size of the unconditional difference shown in Figure 1 (largely the result of controlling for cognitive achievement), it is nonetheless still substantial.

The final two columns of Table 2 examine identical specifications for attendance at four-year PS institutions. Interestingly, achievement appears to have similar effects on attendance at four-year schools in Canada and the U.S., despite the weaker effects of achievement on attendance at any PS institution in Canada. While the effects of parental income in Canada are slightly stronger for attendance at four-year PS institutions than at any PS institution, the effects in the U.S. are still twice as large as in Canada. ${ }^{29}$

We have also explored specifications that use finer measures of achievement (e.g. deciles for mathreading scores) or that include separate quartiles for math and reading achievement. These specifications yield very similar results (for the effects of family income) to those reported in Table 2 (available upon request). Furthermore, Belley and Lochner (2007) show that the effect of parental income in the NLSY97 is largely unchanged when controlling for adolescent participation in criminal activities to account for differences in non-cognitive skills. In the YITS data, Frenette (2007) finds that self-esteem and mastery (feeling control over one's life) play little or no role in explaining the income - university

\footnotetext{
${ }^{27}$ If ability is measured equally well by the ASVAB and PISA tests, then Canada - U.S. differences in the effects of achievement can be attributed to differences in the importance of ability. However, if PISA provides a noisier measure of ability than the ASVAB tests, then we would expect to estimate a weaker relationship between achievement and PS attendance in Canada. Given a positive correlation between ability and parental income, this would likely lead to a small upward bias in the estimated effect of parental income in Canada relative to the U.S.

${ }^{28}$ We control for a very similar set of family background characteristics to those of Belley and Lochner (2007), who explore the changing effects of family income on educational attainment using the NLSY79 and NLSY97. Our estimates for the NLSY97 are very similar to theirs, despite using slightly different measures of achievement and parental income.

${ }^{29}$ We have also estimated the effects of achievement and parental income on attendance at a four-year school conditional on attendance at any PS school. For both countries, achievement has strong positive effects on the likelihood of choosing a four-year institution over a two-year institution, while income has a small effect in Canada and a modest effect in the U.S.
} 
attendance gap after controlling for family background and cognitive achievement.

Given the importance of race and immigration status, we also replicate our analysis for a more restricted sample that is more demographically similar for Canada and the U.S.: white native-born youth with native-born parents. We also restrict the Canadian sample to those with English as their native tongue to best generate a similar ethnic, racial, and cultural sample across the two countries. As column (i) of Appendix Tables A1 and A2 reveal, the effects of income are stronger for this subsample (compared to the results reported in Table 2) in both countries. The effects of income are still twice as strong in the U.S.

An important concern with using family income quartiles to account for a non-linear relationship between income and schooling is the difference in income distributions between the U.S. and Canada. ${ }^{30}$ As is evident from Table 1, income is more dispersed in the U.S., so the gap between high and low income families is greater in the U.S. To see whether this explains the larger educational attainment gaps by parental income quartiles, we estimate specifications analogous to those of Table 2 using linear splines. ${ }^{31}$ This enables us to compare the effects of parental income across countries at any level of income. Figures $3 \mathrm{a}$ and $3 \mathrm{~b}$ plot the estimated effects of income for PS attendance and attendance at a 4-year institution as a function of parental income, normalizing all lines to zero at an income level of $\$ 10,000$. These figures are consistent with Table 2 and show that parental income matters much more in the U.S., whether we use the PPP index or official exchange rates to adjust for currency differences. For PS attendance in general, the effects of income are largely focused in the income range of $\$ 30-80,000$, with much stronger effects in the U.S. throughout this region. For attendance at four-year institutions, the effects of income are generally stronger in the U.S. (relative to Canada) throughout the entire income distribution.

We look more closely at the joint role of achievement and parental income in Table 3, which reports the estimated effects of parental income (using quartile indicators) on attendance at any PS institution and at 4-year PS institutions within each math-reading achievement quartile. These specifications control for the same background characteristics as in Table 2. Among Canadian youth, parental income has modest effects on PS schooling for low-achievement youth but smaller effects on those from higher achievement quartiles. The NLSY97 results show sizeable and statistically significant effects of family income in the U.S. for all achievement groups. Among all but the top achievement

\footnotetext{
${ }^{30}$ We also consider an alternative measure of family income which makes an adjustment for family size. Specifically, we divide parental income by the square root of family size before deriving income quartiles. This income adjustment has little effect on the estimated importance of achievement or parental income.

${ }^{31}$ For comparison with our NPSAS04 analysis of financial aid schedules below, we include spline 'knots' every $\$ 10,000$ from $\$ 20,000$ to $\$ 100,000$, where all amounts are denominated in Canadian dollars.
} 
quartile, moving from the lowest to highest family income quartile raises PS attendance rates by at least 20 percentage points.

\subsection{Differences Across Canadian Provinces and American States}

We now briefly explore whether parental income - PS attendance gradients differ across provinces/states within Canada and the U.S. In Canada, Quebec differs from all other provinces in many ways that may affect income - PS attendance gaps. Not only is Quebec culturally unique, but it also has a very different institutional environment in terms of its structure for higher education and PS aid/costs (see Section 5). Most notably, Quebec charges lower levels of tuition than other Canadian provinces and targets relatively more aid to the bottom of the family income distribution. We also divide American states into those above and below the median in-state public tuition at four-year institutions, $\$ 4,675$. The average difference in tuition between these two groups of states is roughly $\$ 2,300 .{ }^{32}$

Table $4 \mathrm{a}$ presents estimates for specifications identical to our baseline results in Table 2 separately for Quebec and for all other Canadian provinces. Relative to Quebec, estimates for other Canadian provinces reveal slightly stronger effects of parental income on PS attendance but slightly weaker effects on attendance at four-year institutions (i.e. universities). ${ }^{33}$ All estimated effects of income are smaller than their U.S. counterparts.

Estimates for high- and low-tuition states in Table $4 \mathrm{~b}$ also reveal a difference between attendance at any PS institution and at four-year institutions. The first two columns show that family income is much more strongly related to PS attendance in high-tuition states; however, there is little difference in income - attendance gradients for four-year institutions (indeed, the point estimates suggest a slightly weaker income - attendance relationship in high-tuition states). This makes it somewhat difficult to draw strong conclusions about the role of in-state tuition levels on income - attendance relationships within the U.S. As we show below in Section 5, this may not be very surprising given the extent to which financial aid helps offset much of the difference in tuition, especially for families in the bottom half of the income distribution.

\footnotetext{
${ }^{32}$ Median and average tuition levels reported here are based on assuming average state-specific tuition for all individuals in the NLSY97 and then taking the median/mean with respect to all respondents in our sample. Tuition at public twoyear and four-year schools is highly correlated: roughly three-quarters of all individuals with four-year tuition above the median also have two-year tuition above the median. Data on in-state tuition is from Table 313 of the 2005 Digest of Education Statistics (Snyder, et al. 2006).

${ }^{33}$ While not shown, estimates for youth whose first language is French are quite similar to those for the Quebec sample.
} 


\subsection{Accounting for Differences by Local Area of Residence and Peer Groups}

There are many reasons to think that residential segregation by family income may help explain family income - PS attendance relationships. For example, higher income youth may attend 'better' primary and secondary schools or they may live in areas with closer access to PS institutions or more collegelevel jobs. Their peers and social networks are also likely to be more education-friendly. With greater residential segregation by income in the U.S., these factors could contribute to a stronger income attendance relationship there. To explore this possibility, we consider additional specifications that control for local area of residence fixed effects.

Column (ii) in Appendix Table A1 controls for school (at age 15) fixed effects in Canada. ${ }^{34}$ The estimated effects of achievement are remarkably similar to those of Table 2 and the effects of income are only slightly smaller than our baseline estimates. The NLSY97 sampling scheme stratified by geographic area rather than school, so it is not possible to estimate models with school fixed effects. Column (ii) of Table A2 instead estimates our baseline model with fixed effects for county $\times$ MSA residential status at age 15 (not in MSA, in MSA but not central city, in MSA and central city). These estimates are also remarkably similar to their counterparts in Table 2 . This is, perhaps, more surprising given the dramatic differences in schools, inequality, and local labor market conditions across U.S. counties (and metropolitan status within counties).

Column (iii) of Table A1 takes advantage of some unique data collected in YITS related to respondents' perceived returns to schooling and their peers' education plans. The survey asks respondents the extent to which they agree that getting a good job later in life depends on success in school. They are also asked how many of their peers plan to pursue education after high school. Column (iii) reveals that including responses to these questions in our baseline specifications for PS attendance has negligible effects on the estimated achievement and parental income coefficients (compared to Table 2). This is not because perceived returns and peers have no affect on schooling decisions. Our estimates imply that youth who strongly agree that schooling is important for getting a good job in the future are about 8 percentage points more likely to attend PS school than those who strongly disagree with that statement. Furthermore, youth who report that 'all' their peers will attend PS school are about 14 percentage points more likely to attend themselves. While the latter result is not easily interpreted due to concerns about endogeneity bias and correlated unobserved tastes, these findings suggest that our estimated effects of parental income (or achievement) are not driven by differences in peers or views about the returns to education.

\footnotetext{
${ }^{34}$ Due to the YITS sampling scheme, which is stratified by schools, our data contain about 30 students on average in each school.
} 
The fixed effects estimates in Tables A1 and A2 suggest that income plays an important role even within schools or local geographic areas. Of course, peers and social networks may operate on a much more micro level within schools and local residential areas that may not be picked up by school or county $\times$ MSA status fixed effects. Our findings from YITS regarding peers plans for PS schooling and youths' own perceptions about the value of an education suggest that these factors are important determinants of PS choices, but they do not explain the observed correlation between parental income and PS attendance (after controlling for achievement and family background). In the U.S., within-county heterogeneity is likely to be most confounding in more populous areas. Yet, we find similar effects of family income on PS attendance regardless of whether youth come from high or low population density counties. We also estimate similar effects for youth from non-metropolitan or metropolitan areas (see Table A3). However important peers and social networks are, we find no evidence that they explain the parental income - educational attainment relationships we find in the U.S. and Canada (or why this relationship differs across these countries).

By controlling for local residential fixed effects, we also account for differences in local access to a PS institution across individuals. In separate specifications (not shown), we find that the presence of a public PS institution in an individual's county of residence at age 15 has no significant effects on PS attendance rates or the estimated effects of parental income on PS attendance. ${ }^{35}$

Finally, the greater degree of income inequality in the U.S. might suggest that American students face greater uncertainty in their post-school earnings, which may cause youth from low-income families to eschew PS schooling and all the debt it entails. ${ }^{36}$ In this case, we would expect PS attendance decisions for low-income youth to depend more on local labor market conditions (relative to their higher income counterparts); yet, controlling for local residential area fixed effects does not appreciably reduce income - attendance relationships in either Canada or the U.S. We also find no difference in the estimated effect of family income on PS attendance when we split our sample by local unemployment rates (see Table A3).

\footnotetext{
${ }^{35}$ Results available upon request. We thank Janet Currie and Enrico Moretti for providing their data on PS institutions by county. See Currie and Moretti (2003) for further details on these data.

${ }^{36}$ Alternatively, one might wonder if the higher returns to schooling in the U.S. could produce a steeper income - attendance gradient? (See Burbidge, Magee, and Robb (2002) for one study showing higher returns in the U.S.) As shown in Belley, Frenette, and Lochner (2010), a standard schooling choice model with heterogeneous tastes for schooling (with or without credit constraints) suggests that this difference should lead to a weaker, not stronger, income - PS attendance correlation in the U.S.
} 


\subsection{PS Attendance Conditional on High School Completion}

The final column in both Tables A1 and A2 conditions the sample on those who have completed high school. While this does not change the estimated effects of achievement and parental income in Canada (where most students finish high school), these effects are noticeably weaker in the U.S. when compared with Table 2. The estimated effects of income and achievement in column (iii) of Table A2 are roughly half-way between the baseline U.S. and Canada estimates reported in Table 2, suggesting that as much as half of the Canada-U.S. difference in the effects of achievement and parental income on PS attendance may be traced back to the differential effects of achievement and income on high school completion. ${ }^{37}$ Weaker effects of income and achievement conditional on high school completion are also consistent with dynamic self-selection as discussed in Cameron and Heckman (1998). ${ }^{38}$

\section{Post-Secondary Costs and Financial Aid in Canada and the U.S.}

In this section, we discuss tuition costs and financial aid policies in Canada and the U.S. Most notably, we document the relationship between financial aid and parental income in both countries. Before discussing costs and aid, however, we briefly discuss key institutional aspects of higher education in Canada and the U.S.

\subsection{Institutional Environment}

In most Canadian provinces, students obtain a high school diploma after completing twelve years of elementary and secondary schooling. At that point, youth are eligible to begin 'college' (usually a twoor three-year program) or 'university' (usually lasting four years for an undergraduate degree). The province of Quebec differs, however. Students in Quebec normally graduate with a high school diploma after completing 11 years of schooling. Those that want to attend university must first complete a twoyear college program at CEGEP. As a result, Quebec students normally only require three additional years to complete an undergraduate university degree. Those wishing to obtain a terminal college diploma (rather than attend university) must complete a three-year CEGEP program. For the cohort examined in this study, the system also differed in Ontario where most students attending university

\footnotetext{
${ }^{37}$ Belley, Frenette, and Lochner (2010) show that family income has a larger impact on high school completion rates in the U.S. relative to Canada, especially for lower achievement quartiles.

${ }^{38}$ Very low income (or low ability) youth who finish high school are likely to have other unobservable characteristics that make them more likely to continue on in school (e.g. they may enjoy school). This selection is likely to be weaker for high-income (high-ability) youth, who are likely to attend regardless of other factors. As such, conditioning on high school completion may generate a negative correlation between family income (ability) and other unobserved determinants of schooling.
} 
would have attended 13 years of elementary and secondary schooling. ${ }^{39}$

In the U.S., high school completion typically requires twelve years of primary and secondary schooling; however, a state-wide test must also be passed to receive a high school diploma in some states. Students that do not graduate from high school may take the General Educational Development (GED), which is meant to substitute for a high school diploma. In most cases, a high school diploma or GED is required for admission to PS institutions, especially four-year schools.

With the exception of a small number of private career colleges, as well as some elite professional programs at the university level, PS institutions in Canada are heavily funded by the government and are effectively 'public' schools. By contrast, roughly $40 \%$ of all U.S. degree-granting PS institutions are private; however, they only enroll about one-in-four American PS students. About $60 \%$ of all American PS students attend four-year institutions. ${ }^{40}$

\subsection{Post-Secondary Education Finance}

We now discuss the costs of PS attendance and the structure of financial aid programs in Canada and the U.S. ${ }^{41}$ We focus on the following factors determining the financial situation of students in both countries: (i) tuition, fees, and other costs; (ii) expected family contributions (EFC) towards PS schooling; (iii) grants and other non-repayable aid like tax credits; and (iv) student loans. These factors determine both the net price of PS attendance as well as the out-of-pocket expenditures required of students.

We consider costs and aid for the 2003-04 academic year unless otherwise noted, since most of the youth in the NLSY97 and YITS would typically be enrolled in PS school during that year and because we can obtain detailed information about PS financial aid and costs for the U.S. that year from the 2004 National Post-Secondary Aid Survey (NPSAS04). Although comparable individual-specific information about financial aid for students in Canada is not available, the vast majority of aid in Canada is distributed by the federal or provincial governments subject to known rules. We, therefore, use provincial and Canada Student Loan Program (CSLP) rules in 2003-04 to determine financial aid availability for students from different backgrounds. We specifically consider detailed rules in the three

\footnotetext{
${ }^{39}$ Prior to 1999 , university attendance in Ontario required a regular high school diploma (12 years) plus several courses at the OAC (Ontario Academic Credit) level. Although it was possible to complete the OAC requirements by the end of grade 12, very few students did. The Ontario system has since been reformed, such that students beginning in high school in 1999 or later are eligible for university entry after grade 12; however, many students still require an additional year to obtain the advanced credits (King, et al., 2005).

${ }^{40}$ About two-thirds of students in four-year institutions attend public schools, whereas nearly all students enrolled in two-year schools do. These institutional and enrollment statistics are taken from Tables 168 and 243 of the Digest of Education Statistics, 2005 (Snyder, et al. 2006).

${ }^{41}$ Although foregone earnings (i.e. the expected earnings one could receive if not enrolled in school) are an important component of costs, they are roughly similar in Canada and the U.S. (Burbidge, Magee, and Robb 2002).
} 
largest provinces (Quebec, Ontario, and British Columbia) and actual Millennium Foundation awards to determine financial aid (grants and loans) as a function of parental income in those provinces. ${ }^{42}$ Financial aid in most other provinces is similar in nature to that of British Columbia and Ontario.

\subsubsection{Costs}

In 2003-04, average tuition at Canadian universities was $\$ 4,025$. Adding expenses for books, supplies, housing, and transportation, typically implied total costs to students of more than $\$ 10,000$ per year. Tuition levels at two-year colleges are roughly half that of university levels (except in Quebec), and more youth have local access to colleges than universities, reducing additional costs associated with housing and transportation. Variability in tuition is quite small in Canada relative to the U.S. At the college level, tuition is remarkably similar across programs and most provinces; although, Quebec is a clear exception, where in-province CEGEP students pay only nominal registration fees. At the university level, tuition varies somewhat from about $\$ 2,500$ in Quebec to $\$ 4,800$ in British Columbia to $\$ 5,600$ in Ontario. ${ }^{43}$

Average tuition levels are much higher in the U.S. than in Canada due to the sizeable share of private PS institutions in the U.S. Differences between Canadian and U.S. public school tuition levels are more modest. In the 2003-04 academic year, average tuition and fees for undergraduates in the U.S. amounted to $\$ 1,900$ at two-year public schools, $\$ 4,600$ at four-year public schools, and $\$ 19,000$ at four-year private schools (College Board 2004). Adjusting for the relevant PPP inflates these U.S. costs by about $20 \%$, so American students who choose in-state public PS schools typically face costs that are about $40 \%$ higher than those faced by their Canadian counterparts. Of course, tuition and fees vary substantially across U.S. states (and, to a lesser extent, Canadian provinces) as we discuss below.

Among four-year students living away from home, room and board charges added another six to seven thousand dollars in both Canada and the U.S. (Usher and Steele 2006). Of course, living at home can save considerably on these costs. Do (2004) notes that about half of U.S. high school graduates do not have local access to a state-funded PS institution, while Frenette (2004) finds that only one-in-six Canadian students do not have access to a local university and nearly all Canadian students have local access to a two-year college. These differences appear to be important for residential choices given that $35 \%$ of recent dependent university students who received CSLP aid in Canada lived with their

\footnotetext{
${ }^{42}$ Roughly $75 \%$ of the Canadian population resides in Quebec, Ontario, or British Columbia.

${ }^{43}$ Within provinces, tuition is fairly similar across programs and institutions, except for a few recently de-regulated elite professional programs (especially in Ontario). See Junor and Usher (2004) for a detailed description of PS costs and financial aid in Canada.
} 
parents while only $20 \%$ of their American counterparts did. ${ }^{44}$

University attendance rates have traditionally been lower among 'distant' students, especially those from disadvantaged families (Card 1995, Kling 2001, Frenette 2004). However, Kling (2001) and Cameron and Taber (2004) suggest that living near a post-secondary school was less important in the U.S. during the early 1980s than it was twenty years earlier. We find no difference in family income - PS attendance gaps in the NLSY97 for students with or without a public PS institution in their county of residence at age 15 .

\subsubsection{Financial Aid}

Both Canada and the U.S. provide considerable aid in the form of grants (including loan remissions in Canada), tax credits, and loans. In both countries, the vast majority of financial aid is need-based; although, merit-based aid has grown recently in the U.S. ${ }^{45}$ We focus on need-based aid in Canada and the U.S., since we are primarily interested in understanding PS attendance gaps by family income conditional on adolescent student achievement.

Throughout most of Canada, student grants and loans are administered through (or in concert with) the Canada Student Loan Program (CSLP) with the federal government providing 60\% of student assessed need and provincial governments the rest. (Quebec is an exception with its own student financial aid system.) The Millennium Foundation also provided considerable grant and bursary aid in 2003-04, which we account for in our figures below. While the details of provincial aid programs differ, all provide some combination of loans and grants based on student need. In the U.S., federal rules determine federal grants and loans as a function of student need. Most states and institutions use a similar need calculation in determining their support.

Generally, determined 'need' simply equals total estimated costs (including tuition, fees, living expenses, books and equipment, and travel expenses) less an expected family contribution (EFC). While actual EFCs differ between Canada and the U.S., they are based on similar information.

\footnotetext{
${ }^{44}$ Canadian residential status figures are based on dependent students receiving some form of aid from the CSLP (excludes Quebec) in 2004-05. (We thank Leesha Lin from the CSLP for providing us with these statistics from the Provincial Need Assessment Data.) Among 19-year old Canadians surveyed (by YITS) in 2004, 48\% of those who had attended university reported living with their parents in December 2003 ; this figure drops to $42 \%$ for those in university four years later at age 23. These figures are likely higher than that for all CSLP aid recipients, since students living with their parents are less likely to qualify for financial aid. The U.S. figure is based on all full time/full-year dependent students ages 18-24 who applied for federal aid and attended an in-state 4-year public institution in 2003-04 (based on NPSAS04).

${ }^{45}$ In Canada, roughly $\$ 200$ million is provided annually in the form of merit aid, compared with over $\$ 6$ billion in federal and provincial aid (Berger, Motte, and Parkin 2007). Some U.S. states have introduced scholarships and grants for students who perform well in high school and attend PS school in-state (many based on the success of Georgia's Hope Scholarship Program). PS institutions themselves exercise flexibility in their financial aid packages, sometimes using generous offers to attract top students. This is most common in the most expensive private schools and less common in public institutions.
} 
EFCs depend on a student's own savings and income, as well as that of his parents (dependent students) or spouse (married students). ${ }^{46}$ Canadian students in provinces other than Quebec are expected to contribute all of their savings towards post-secondary schooling, while student savings are fully exempt in Quebec. American students are expected to contribute 35\% of any savings. Because most traditional students accumulate little savings, these differences are relatively unimportant. More importantly, Canada and the U.S. differ substantially in the way they treat student income in calculating the EFC. In Canada, students are expected to contribute a minimum amount each year from summer employment, with any additional income above a modest living amount taxed at rates typically above $80 \%$. Minimum contribution rates can be sizeable, ranging between two and three thousand dollars in most provinces. ${ }^{47}$ In contrast, the U.S. imposes no minimum contribution from students, instead allowing them to earn $\$ 2,380$ before 'taxing' them at a $50 \%$ rate. This differential treatment of student income plays an important role in determining EFCs and financial aid at the low end of the parental income distribution in the U.S. and Canada.

Expected parental contributions depend primarily on parental income in both countries, with assets playing only a minor role. ${ }^{48}$ Generally, parents with income below an exemption amount are not expected to contribute to their children's PS education. Exemption levels are relatively low in the U.S. and Quebec compared to other Canadian provinces. Parents earning above the exemption level are effectively taxed by financial aid formulas as their expected contribution rises with income.

Figure 4 shows EFCs as a function of pre-tax parental income for students from two-parent/twochild families in British Columbia, Ontario, and Quebec. ${ }^{49}$ The figure also reports average EFC amounts by parental income for dependent undergraduate students in the U.S. from the NPSAS04. (Note that U.S. dollars in this and other figures of this section have been inflated by $20 \%$ reflecting the PPP difference between Canada and the U.S.) The differential treatment of student contributions

\footnotetext{
${ }^{46}$ Parental resources are not considered for independent students. In Canada, a student must typically be married, have children, been in the workforce for at least 2 years, or been out of secondary school for at least 4 years $(5$ years in Ontario, out of full-time studies for 7 years in Quebec) in order to be considered independent. In the U.S., independent students must be over age 24 , married, or with children.

${ }^{47}$ Students in Quebec and BC are expected to contribute between $\$ 2,500$ and $\$ 3,000$ each year, while students from Ontario are only expected to contribute $\$ 1,800$ annually. In some cases, students may be given an exemption from the minimum contribution if they are unable to find summer employment. Exemption rates vary from year to year, but for 2004-05, 23\% of dependent university students from British Columbia and 5\% of students from Ontario received an exemption. (We thank Leesha Lin from the CSLP for providing us with these exemption rates from the Provincial Need Assessment Data.)

${ }^{48}$ Parental assets are generally exempt throughout Canada, except in Quebec where expected parental contributions increase by $2 \%$ for assets above $\$ 90,000$ ( $\$ 250,000$ for farmers and fishermen). In the U.S., all housing assets are exempt, along with any assets below the appropriate exemption amount (e.g. $\$ 37,300$ for a two-parent family with the older parent 40 years old). Above the exemption amount, assets are multiplied by 0.12 and then added to parental income in determining expected parental contributions.

${ }^{49}$ See Appendix D (available online) for a detailed discussion of EFC and aid calculations in Canada.
} 
from summer work is evident at the low end of the income scale, where the U.S. expects much less from disadvantaged families. However, the EFC increases quickly in the U.S., overtaking the EFCs in Ontario and British Columbia at around \$30-35,000. Implicit tax rates on parental income above the exemption level are modest but cover a broad range of incomes for the U.S. and Quebec, whereas in other Canadian provinces, implicit tax rates on non-exempt income are higher but only apply to families earning above $\$ 55,000$ (slightly below the median family income for our YITS sample).

In Canada, government student aid is offered to cover the difference between costs and the EFC, subject to a generous upper limit. (Institutions themselves sometimes provide additional aid to help meet any need that has not been satisfied by federal and provincial sources; however, institutional aid plays a minor role in Canada relative to the U.S.) In most provinces, total government aid (loans plus grants) is limited to no more than $\$ 275$ per week ( $\$ 9,350$ for a typical 34 -week academic year) for single dependent students. While a few provinces offer slightly higher limits, Quebec sets much higher annual limits of $\$ 14,792$ (CEGEP) and $\$ 17,293$ (university undergraduates). Generally, government loans are the first form of aid provided, with grants reserved for those with the greatest need. The mix between grants and loans is largely a provincial decision. Again, Quebec differs substantially from the rest of Canada in favoring grants heavily over loans. Quebec limits loan amounts to about $\$ 2,500$ per year for university undergraduates ( $\$ 2,000 / y r$ for CEGEP students), providing all other aid in the form of grants. Other provinces typically offer more of their assistance in the form of loans. See Appendix D (available online) for further details.

Most federal grant aid in the U.S. is distributed in the form of Pell grants, targeted to very low income families. (In 2003-04, the maximum Pell grant award was $\$ 4,050$, while the maximum Supplemental Educational Opportunity Grant was $\$ 4,000$.) States and institutions are also an important source of grant aid, especially for students from middle and higher income families. The Stafford Loan Program offers loans to all students (regardless of need) of up to $\$ 2,625$ for the first year of PS schooling, $\$ 3,500$ for the second year, and $\$ 5,500$ for each of the next three years. ${ }^{50}$ The total amount of federal grants and subsidized loans cannot exceed the total cost of tuition, fees, room and board (TFRB) less the EFC. However, all students can take out unsubsidized Stafford loans up to maximum loan limits or the total cost of schooling (less any subsidized loan amounts) regardless of calculated need. In this respect, the U.S. federal aid system is more generous to youth from higher income families compared to the Canadian system. Canada does not offer government student loans

\footnotetext{
${ }^{50}$ These limits have increased since 2003-04. Low-income students may receive subsidized Stafford Loans, for which the government pays the interest while the student is enrolled in a PS school, as well as Perkins Student Loans. Higher income students can take out unsubsidized Stafford Loans.
} 
irrespective of need, so students with parents providing little financial support may have difficulties making ends meet.

In Figures 5-8, we show how financial aid, net tuition, and out-of-pocket schooling costs for PS students attending four-year institutions in Canada and the U.S. depend on parental income. Canadian figures are based on the CSLP and provincial rules (including Millennium and provincial grants and bursaries), using province-specific information about average university costs and student residential status. We focus on the three largest Canadian provinces (British Columbia, Ontario, and Quebec); however, patterns for other provinces are governed by similar rules to those of British Columbia and Ontario (see, e.g., Junor and Usher, 2004). Figures for the U.S. are calculated from the NPSAS04 and are based on 18-24 year-old dependent students that are enrolled in-state in a public four-year PS institution and applied for federal financial aid. ${ }^{51}$ We separately consider students attending high and low tuition institutions in the U.S. based on whether the student pays more or less than the median level of tuition $(\$ 4,350) .{ }^{52}$ Average tuition for the bottom half is $\$ 3,300$, while it is $\$ 6,000$ for the top half. Aid figures for Canada are reported separately for students living at 'home' with their parents and those living 'away' from their parents. Surprisingly, average aid amounts differ very little by student residential status in the U.S. We, therefore, show averages for American students regardless of residential status.

Figure 5 reports total non-repayable aid, including tax credits, grants, scholarships and bursaries, by parental income. ${ }^{53}$ (See Appendix B for a discussion of non-repayable aid disaggregated by source.) American students with parental income below $\$ 20,000$ received roughly $\$ 10,000$ in non-repayable aid from high tuition states and approximately $\$ 7,000$ from low tuition states. This difference nearly compensates for the difference in tuition. The figure also shows how non-repayable aid (in particular, grant and scholarship aid) declines sharply and continuously with income in the U.S. for families earning less than $\$ 60,000$. Total non-repayable aid (especially grants and bursaries) in Canada is generally much lower and varies considerably by student residential status, reflecting the difference in costs. As noted earlier, Quebec provides all aid in the form of grants above $\$ 2,500$; however, Ontario and British Columbia simply have a cutoff need level, above which students receive Millennium or provincial bursaries/grants and below which they do not. ${ }^{54}$ Non-repayable aid for Quebec follows

\footnotetext{
${ }^{51}$ Using the NPSAS04, we calculate average aid for parental income categories (adjusted for PPP) zero to twenty thousand dollars, then by every ten thousand dollars up to one hundred thousand dollars, and for one hundred thousand dollars and above.

${ }^{52}$ This distinction is largely synonymous with living in high or low tuition states, since variation in in-state tuition across four-year institutions within states is quite small.

${ }^{53}$ We also include loan remissions in total non-repayable aid for Ontario and Quebec.

${ }^{54}$ Through loan remissions, Ontario effectively limits loans to $\$ 7,000$ and provides all aid above that amount in the form of grants. The modest increases in aid at very low income levels in Canada are due to the inability of very low
} 
a similar pattern to that of the U.S., phasing out continuously over the bottom half of the income distribution. By contrast, non-repayable aid in British Columbia and Ontario phases out quite quickly but at much higher income levels.

Figure 6 reports available government loans in the U.S. and Canada. U.S. amounts assume all students can access Stafford Loans up to the maximum limits; they also include any need-based loans (e.g. Perkins loans) as reported by the NPSAS04. Government student loan access is largely independent of parental income in the U.S. This is not true in Canada, where loans phase-out over a similar income range as does grant aid. In Ontario and British Columbia, both grants and loans are available up to fairly high income levels (roughly $\$ 70,000$ for students living away from home), then phase-out very quickly.

Figure 7 subtracts total non-repayable aid from tuition and fees to obtain a measure of 'net tuition' at public four-year institutions. This measure does not account for living expenses, which are typically estimated at \$6-7 thousand for students living away from home. So, while net tuition appears to be higher for Canadian students living at home, the total net cost of university may be lower. Because financial aid and net tuition figures for the U.S. differ little by residential status, total net costs are noticeably higher for American students living on their own.

A few general comments about net tuition are in order. First, the U.S. is, on average, relatively generous at the low end of the income distribution, even among high tuition states. The Canada U.S. difference in net tuition for very low income families largely reflects the differential treatment of student income by EFC formulas: Canada expects all students to pay $\$ 2-3$ thousand towards their own education while the U.S. does not. Quebec is also quite generous due to its emphasis on grants over loans. Indeed, net tuition as a function of family income is remarkably similar for Quebec (students living away from their parents) and low tuition states in the U.S. Second, net tuition increases substantially with income over the bottom half of the distribution (up to around $\$ 60,000$ ) in the U.S. and Quebec. In Ontario and British Columbia, net tuition is largely independent of family income until it reaches about $\$ 65-75,000$, at which point it jumps up $\$ 2-3$ thousand. In practice, net tuition is likely to increase more smoothly than reflected in the figure for Ontario and British Columbia due to institutional grants and scholarships not considered here; however, institutional aid does not play a major role in Canada. ${ }^{55}$ Thus, it is highly unlikely that net tuition rises as much with income in these provinces as it does in either the U.S. or Quebec. Third, net tuition differs across U.S. states

\footnotetext{
income families to fully benefit from education tax credits.

${ }^{55}$ Differences in family assets, youth earnings, and calculated living/travelling costs across individuals would also tend to smooth out financial aid as a function of income in Canada.
} 
depending on state-determined tuition levels and state/institutional aid policies. Although roughly $80 \%$ of all in-state students from families earning less than $\$ 20,000$ have negative net tuition levels in the U.S., $8 \%$ pay more than $\$ 1,500$ in net tuition. Most of the variation, especially in net tuition levels, occurs across high-tuition states. Variation in net tuition across low-tuition states is relatively modest. Finally, it is important to recognize that all NPSAS04 figures for the U.S. are based on students choosing to enroll in a four-year public institution. It is possible that students receiving less generous financial aid offers never enroll in the first place, so our total grant figures may be biased upwards and net tuition figures downwards compared to the amounts a typical potential student might face. In Appendix B, we consider bounds on net tuition and out-of-pocket costs (by parental income) to account for this self-selection. As Figures B3 and B4 show, assuming that youth who do not attend PS school would have received zero institutional grant aid produces qualitatively similar conclusions. ${ }^{56}$

In addition to the net price of attendance, out-of-pocket costs may be an important determinant of PS attendance for youth who have limited access to credit. Figure 8 shows out-of-pocket expenses, defined as net tuition less available government loans, for Canada and the U.S. This reflects the total amount of money students are expected to raise on their own (or from parents or other relatives) each year to finance tuition costs. On average, the U.S. is relatively generous at the low end of the income distribution; however, total available aid (repayable and non-repayable) is more generous in British Columbia and Ontario for middle income families. While Quebec is generous in terms of grant aid, it is not in terms of total aid. As a result, out-of-pocket expenses are relatively high in Quebec compared to other Canadian provinces and the U.S. Out-of-pocket expenses in Ontario and British Columbia do not depend much on parental income for lower and middle income families; however, they rise considerably with income among higher income families. The value of the Stafford Loan program in the U.S. for students from high-income families is evident in their low out-of-pocket expenditures relative to their Canadian counterparts.

Private loans are also a growing source of financing for undergraduate students in both the U.S. and Canada. Unfortunately, we are unable to compare Canada and the U.S. with respect to private student credit by parental income; however, overall private student borrowing amounts appear to be roughly similar. ${ }^{57}$

\footnotetext{
${ }^{56}$ Average net tuition for very low income youth is noticeably higher in high tuition states if we assume non-attendees would not have received any institutional or state aid; however, this bound is extremely conservative given the amount of state aid that is disbursed.

${ }^{57}$ In the U.S., private student loans represented $16 \%$ of all student loan dollars taken out in 2003-04 (College Board 2006). Junor and Usher (2004) report that roughly $15 \%$ of Canadian students reported taking out a private student loan in 2001-02 (with average annual loan amounts of $\$ 5,600$ ).
} 


\section{Tuition, Financial Aid, and Family Income - Post-Secondary At- tendance Patterns}

The relationship between net tuition and family income is important, since it determines the price paid by different types of families. It is clear that lower net tuition levels should encourage PS attendance among individuals from all backgrounds regardless of whether families have adequate access to credit. By contrast, out-of-pocket expenditures are likely to affect attendance decisions only for those families that face cash-flow problems arising from imperfect credit markets. As discussed in Section 2, the literature has reached some degree of consensus on the effects of tuition and aid on PS attendance; however, much less is known about the importance of borrowing constraints and the role of out-ofpocket expenditures (or student loan amounts).

Net tuition in the U.S. and Quebec increases substantially as parental income rises. Increases are more modest in British Columbia and Ontario (see Figure 7). These differences in net tuition imply that low-income Americans and Quebecois should have much higher attendance rates than their higher income counterparts, while the same differences in $\mathrm{BC}$ and Ontario should be noticeably smaller. Of course, many other factors may generate a positive income - attendance relationship. Still, in light of the much more targeted nature of need-based grant aid in the U.S., it is surprising that income attendance gaps are so much stronger in the U.S.

Required out-of-pocket expenditures may also affect the relationship between family income and PS attendance due to borrowing constraints. It is, therefore, noteworthy that the general relationship between out-of-pocket expenditures and parental income (see Figure 8) is quite similar to that of net tuition at the bottom of the income distribution, reinforcing the prediction (at least among youth whose parents earn less than $\$ 60,000)$ that the income - attendance relationship should be weaker in the U.S. than in Canada.

$\mathrm{BC}$ and Ontario sharply reduce both grant and loan aid at the top of the income distribution. This leads to steep but modest increases in net tuition and substantial increases in out-of-pocket costs as income rises above $\$ 60,000$ (see Figures 7 and 8 ). By contrast, most need-based aid has been exhausted in the U.S. and Quebec. These patterns imply steeper family income - PS attendance relationships in the U.S. and Quebec (compared to BC and Ontario) for upper-middle and upperincome families. While income - attendance gradients are indeed steeper in the U.S. (throughout the income distribution), they are quite similar between Quebec and other Canadian provinces. 


\subsection{Quantifying the Role of Need-Based Financial Aid}

Our results generally suggest that the underlying demand for PS education is much more strongly increasing in family income among American youth than among Canadian youth. The greater targeting of aid to low-income families in the U.S. (largely due to federal Pell Grants) most likely dampens an otherwise greater discrepancy. This raises two interesting questions: (1) What would happen to family income - PS attendance relationships if non-repayable need-based aid were eliminated? (2) How much more non-repayable need-based aid would be needed to eliminate family income - PS attendance gaps (conditional on student achievement and family background). The answer to (1) not only provides a useful measure of the importance of current need-based aid policies, but it also provides a measure of the underlying difference in demand for PS education by family income. (Appendix C provides details on the calculations presented here.)

The literature surveyed in Section 2.2 suggests that a $\$ 1,000$ change in non-repayable aid leads to a 3-5 percentage point change in PS attendance for the affected group. Based on these consensus estimates, Figure 9 shows how PS attendance rates are predicted to change (by family income) in Canada and the U.S. if non-repayable aid amounts for all families were reduced to the amounts reported for families with incomes above $\$ 100,000 .{ }^{58}$ While the figure reports overall income - attendance gaps, the same changes would be observed for gaps conditional on family background and adolescent achievement. We see that the reductions in aid would cause American (Canadian) youth from families earning $\$ 25,000$ to reduce their PS attendance rates by 14-23 (8-13) percentage points, whereas reductions would be less than 4 (2) percentage points for youth from families earning $\$ 75,000 .{ }^{59}$ Put another way, eliminating need-based aid would roughly double conditional income - attendance gaps in the U.S. and Canada. Also, notice that even if U.S. aid had no effect on attendance, while aid in Canada had effects of 3-5 percentage points per $\$ 1,000$, income - attendance relationships would still be steeper in the U.S.

Figure 10 shows how much additional non-repayable aid would need to be offered to students from different family income backgrounds to completely eliminate the relationship between income and attendance conditional on family background and cognitive achievement (see Figures 3a and 3b). Financial aid would need to increase by $60-100 \%$ for low-income students in both countries. Of course, this would require substantially larger outlays in the U.S. where current aid levels are already relatively high for those at the bottom of the income distribution.

\footnotetext{
${ }^{58}$ As seen in Figure 5, this would not actually eliminate all non-repayable aid, since even students from very high income families receive tax credits (and, in the U.S., some institutional and state aid).

${ }^{59}$ Estimates for Canada take population-weighted averages for British Columbia, Ontario, and Quebec.
} 


\section{Conclusions}

Education is central to future labor market success, so it is important to know whether youth from low-income backgrounds are taking full advantage of higher education systems. If they are not, then intergenerational mobility is likely to be severely limited. Our findings suggest that this concern is more pronounced in the U.S. than in Canada. In particular, we show that PS attendance rates among recent cohorts are more strongly related to parental income in the U.S. than in Canada, even after controlling for similar measures of family background, adolescent cognitive achievement, and local area of residence fixed effects. Our estimates, therefore, suggest that the stronger U.S. income attendance relationship is not simply explained by Canada - U.S. differences in the correlation between family income and student ability, residential segregation, peers/social networks, local labor market conditions, or local access to PS institutions.

One common concern is that a lack of adequate credit prevents lower income youth from attending PS school. To explain the stronger income - attendance relationship in the U.S., these constraints would need to be more binding in the U.S. Yet, we show that out-of-pocket expenditures are lower, on average, for low-income American youth compared to their Canadian counterparts. We also observe that PS attendance increases with family income even among middle- and upper-income families in both Canada and the U.S. Family income is also more strongly related to high school completion in the U.S. relative to Canada (Belley, Frenette, and Lochner 2010). However important borrowing constraints may be, they are unlikely to explain much of the Canada - U.S. difference in family income - PS attendance patterns.

It is also possible that the stronger family income - PS attendance relationship in the U.S. is driven by a stronger correlation between income and tastes for schooling. If so, this stronger correlation must exist within narrowly defined communities conditional on a broad set of observable family background characteristics (e.g. parental education, race, family composition). Additionally, to fully explain the evolution of family income - PS attendance rates in the U.S. since the early 1980s (when family income - PS attendance gaps were as weak as they are today in Canada), this correlation would need to have strengthened considerably over time in the U.S. While we are skeptical of this, we leave a serious treatment of this hypothesis to future research.

Our primary aim is not to fully account for U.S. - Canada differences in the relationship between family income and PS attendance. Instead, we focus on understanding the extent to which the overall structure of Canadian and American financial aid programs contribute to these attendance patterns regardless of their underlying causes. Both countries spend billions each year on financial aid in the 
pursuit of greater educational equity - it is important to know what this money 'buys'. We, therefore, undertake a careful accounting of all need-based financial aid in Canada and the U.S., documenting the dependence of net tuition and out-of-pocket expenditures on family resources.

We show that the U.S. provides more aid than Canada at the bottom of the income distribution but quickly 'taxes' non-repayable aid away as parental income rises toward the median. Canada provides similar aid to low- and middle-income families, 'taxing' both non-repayable and loan aid away quickly for families above the median. Overall, the U.S. is relatively more generous at the low (and high) end of the income distribution, while Canada is more generous in the middle.

Consensus estimates of the impact of tuition and aid on PS attendance imply an important role for need-based aid in shaping family income - PS attendance relationships and, by extension, intergenerational mobility in both the U.S. and Canada. Combining these estimates with the structure of financial aid, we show that income - attendance relationships would be roughly twice as strong as they are now (in both the U.S. and Canada) in the absence of any need-based aid. Furthermore, the relationship between income and PS attendance would be even more pronounced in the U.S. relative to Canada (in absolute terms) in the absence of need-based aid. Thus, underlying differences in the demand for education by family income appear to be much stronger in the U.S. Although we are unable to fully determine why, our analysis casts doubt on many common explanations. We also demonstrate that eliminating the relationship between income and attendance (conditional on family background and cognitive achievement) would require substantial increases in aid for both countries, but more so in the U.S.

\section{References}

Abraham, K., and M. Clark (2006), "Financial Aid and Students College Decisions: Evidence from the District of Columbia Tuition Assistance Grant Program", Journal of Human Resources, 41(3), 578-610.

Belley, P., and L. Lochner (2007), "The Changing Role of Family Income and Ability in Determining Educational Achievement", Journal of Human Capital, 1(1), 37-90.

Belley, P., M. Frenette, and L. Lochner (2010), "Post-Secondary Attendance by Parental Income: Comparing the U.S. and Canada", Working Paper.

Berkner, L. (2000), Trends in Undergraduate Borrowing: Federal Student Loans in 1989-90, 1992-93, and 199596, Washington DC: National Center for Education Statistics Report 2000-151.

Berger, J. A. Motte, and A. Parkin (2007), The Price of Knowledge: Access and Student Finance in Canada, Montreal: Canada Millenium Scholarship Foundation. 
Bettinger, E., B.T. Long, P. Oreopoulos, and L. Sanbonmatsu (2009), "The Role of Information and Simplification in College Decisions: Results from the H\&R Block FAFSA Experiment", Working Paper.

Bishop, J. (1977), "The Effect of Public Policies on the Demand for Higher Education", Journal of Human Resources 12(3), 285-307.

Blackburn, M., and D. Neumark (1993), "Omitted-Ability Bias and the Increase in the Return to Schooling", Journal of Labor Economics, 11, 521-44.

Burbidge, J.B, L. Magee, and A.L. Robb (2002), "The Education Premium in Canada and the United States", Canadian Public Policy, 28(2), 203-27.

Brown, M., J.K. Scholz, and A. Seshadri, (2011) "A New test of Borrowing Constraints for Education," Working paper.

Cameron, S., and C. Taber (2004), "Estimation of Educational Borrowing Constraints Using Returns to Schooling", Journal of Political Economy, 112, 132-82.

Cameron, S., and J.J. Heckman (1998), "Life Cycle Schooling and Dynamic Selection Bias: Models and Evidence for Five Cohorts of American Males", Journal of Political Economy, 106, 262-333.

Cameron, S., and J.J. Heckman (2001), "The Dynamics of Educational Attainment for Black, Hispanic and White Males", Journal of Political Economy, 109, 455-99.

Card, D. (1995), "Using Geographic Variation in College Proximity to Estimate the Returns to Schooling", in L.N. Christofides et al. (eds.), Aspects of Labour Market Behaviour: Essays in Honor of John Vanderkamp, Toronto: University of Toronto Press, 201-21.

Carneiro, P., and J.J. Heckman (2002), "The Evidence on Credit Constraints in Post-Secondary Schooling", Economic Journal, 112, 989-1018.

Carneiro, P. and J.J. Heckman (2003), "Human Capital Policy", in J.J. Heckman and A. Krueger (eds.) Inequality in America: What Role for Human Capital Policies?, Cambridge, MA: MIT Press.

Cawley, J., J.J. Heckman, L. Lochner and E. Vytlacil (2000), "Understanding the Role of Cognitive Ability in Accounting for the Recent Rise in the Economic Return to Education", in K.J. Arrow, S. Bowles and S. Durlauf (eds.), Meritocracy and Economic Inequality, Princeton, NJ: Princeton University Press.

Christofides, L., J. Cirello, and M. Hoy (2001), "Family Income and Postsecondary Education in Canada", The Canadian Journal of Higher Education, 31(1), 177-208.

Corak, M., G. Lipps, and J. Zhao (2003), Family Income and Participation in Post-Secondary Education, Analytical Studies Branch Research Paper Series. Catalogue no 11F0019MIE2003210. Ottawa: Statistics Canada.

College Board (2004), Trends in College Pricing 2004, Washington DC: College Board. 
College Board (2006), Trends in Student Aid 2006, Washington DC: College Board.

Currie, J., and E. Moretti (2003), "Mother's Education and the Intergenerational Transmission of Human Capital: Evidence from College Openings", Quarterly Journal of Economics, 118(4), 1495-1532.

Deming, D., and S. Dynarski (2009), "Into College, Out of Poverty? Policies to Increase the Postsecondary Attainment of the Poor", NBER Working Paper No. 15387.

Do, C. (2004), "The effects of local colleges on the quality of college attended", Economics of Education Review, $23(3), 249-57$.

Dynarski, S. (2000), "Hope for Whom? Financial Aid for the Middle Class and Its Impact on College Attendance", National Tax Journal 53(3), 629-661.

Dynarski, S. (2003), "Does Aid Matter? Measuring the Effect of Student Aid on College Attendance and Completion", American Economic Review, 93(1), 279-288.

Ellwood, D., and T. Kane (2000), "Who Is Getting a College Education? Family Background and the Growing Gaps in Enrollment", in S. Danziger and J. Waldfogel (eds.), Securing the Future: Investing in Children from Birth to College, Russell Sage Foundation.

Fortin, N. (2005), "Rising Tuition and Supply Constraints: Explaining Canada - U.S. Differences in University Enrollment Rates", in C. Beach, R.W. Boadway, Robin W., and R. M. McInnis (eds.), Higher Education in Canada, John Deutsch Institute, McGill-Queens University Press, 369-413.

Frenette, M. (2004), "Access to College and University: Does Distance Matter?" Canadian Public Policy, 30(4), $427-43$.

Frenette, M. (2005), "Is Post-Secondary Access More Equitable in Canada or the United States?" Statistics Canada, Analytical Studies Branch Research Paper No. 244.

Frenette, M. (2007), "Why are Youth from Lower-Income Families Less Likely to Attend University? Evidence from Academic Abilities, Parental Influences, and Financial Constraints", Statistics Canada, Analytical Studies Branch Research Paper No. 295.

Hansen, W.L. (1983), "Impact of Student Financial Aid on Access". In: Froomkin, J. (Ed.), The Crisis in Higher Education, Academy of Political Science, New York, pp. 84-96.

Heckman, J.J., L. Lochner, and P. Todd (2008), "Earnings Functions and Rates of Return", Journal of Human Capital, 2(1), 1-31.

Junor, S., and A. Usher (2004), The Price of Knowledge: Access and Student Finance in Canada, Montreal: Canada Millenium Scholarship Foundation.

Kane, T. (1994), "College Attendance by Blacks since 1970: The Role of College Cost, Family Background and the Returns to Education". Journal of Political Economy, 102 (5), 878-911. 
Kane, T. (1999), The Price of Admission: Rethinking How Americans Pay for College, Brookings Institution Press (with Russell Sage Foundation), Washington, DC.

Kane, T. (2003), "A Quasi-experimental Estimate of the Impact of Financial Aid on College-going", NBER Working Paper No. 9703.

Kane, T. (2006), "Public Intervention in Post-Secondary Education," in E. Hanushek and F. Welch (eds.), Handbook of the Economics of Education, Vol. 2, Ch. 23, Amsterdam: Elsevier Science.

Kane, T. (2007), "Evaluating the Impact of the D.C. Tuition Assistance Grant Program", Journal of Human Resources 42(3), 555-582.

Keane, M., and K. Wolpin (2001), "The Effect of Parental Transfers and Borrowing Constraints on Educational Attainment", International Economic Review, 42, 1051-1103.

King, A.J., W.K. Warren, J.C. Boyer, and P. Chin (2005), Double Cohort Study: Phase 4, Queen's University: Social Program Evaluation Group. Report submitted to the Ontario Ministry of Education.

Kling, J. (2001), "Interpreting Instrumental Variables Estimates of the Returns to Schooling", Journal of Business \& Economic Statistics, 19(3), 358-64.

Krueger, A. (2003), "Inequality: Too Much of a Good Thing", in J.J. Heckman and A. Krueger (eds.) Inequality in America: What Role for Human Capital Policies?, Cambridge, MA: MIT Press.

Leslie, L., and P.T. Brinkman (1987), "Student Price Response in Higher Education: The Student Demand Studies", Journal of Higher Education 58(2), 181-204.

Leslie, L., and P.T. Brinkman (1988), Economic Value of Higher Education, MacMillan, New York.

Lochner, L., and A. Monge-Naranjo (2010), "The Nature of Credit Constraints and Human Capital", Working Paper.

Lovenheim, M. (2011), "The Effect of Liquid Housing Wealth on College Enrollment", Working Paper.

Manski, C., and D. Wise (1983), College Choice in America, Cambridge, MA: Harvard University Press.

McPherson, M., and M. Schapiro (1991), "Does Student Aid Affect College Enrollment? New Evidence on a Persistent Controversy", American Economic Review 81(1), 309-318.

Murnane, R., J. Willett, and F. Levy (1995), "The Growing Importance of Cognitive Skills in Wage Determination", Review of Economics and Statistics, 77, 251-266.

Snyder, T., A. Tan, and C. Hoffman (2006), Digest of Education Statistics 2005, NCES 2006-030, U.S. Department of Education, National Center for Education Statistics, Washington, DC: U.S. Government Printing Office.

Titus, M. (2002), Supplemental Table Update for Trends in Undergraduate Borrowing: Federal Student Loans in 1989-90, 1992-93, and 1995-96, http://nces.ed.gov/pubs2000/2000151update.pdf.

Usher, A., and K. Steele (2006), The State of Student Aid in Canada, Toronto: Educational Policy Institute. 
Figure 1: PSE Attendance by Parental Income Quartiles in Canada (YITS) and the US (NLSY97)
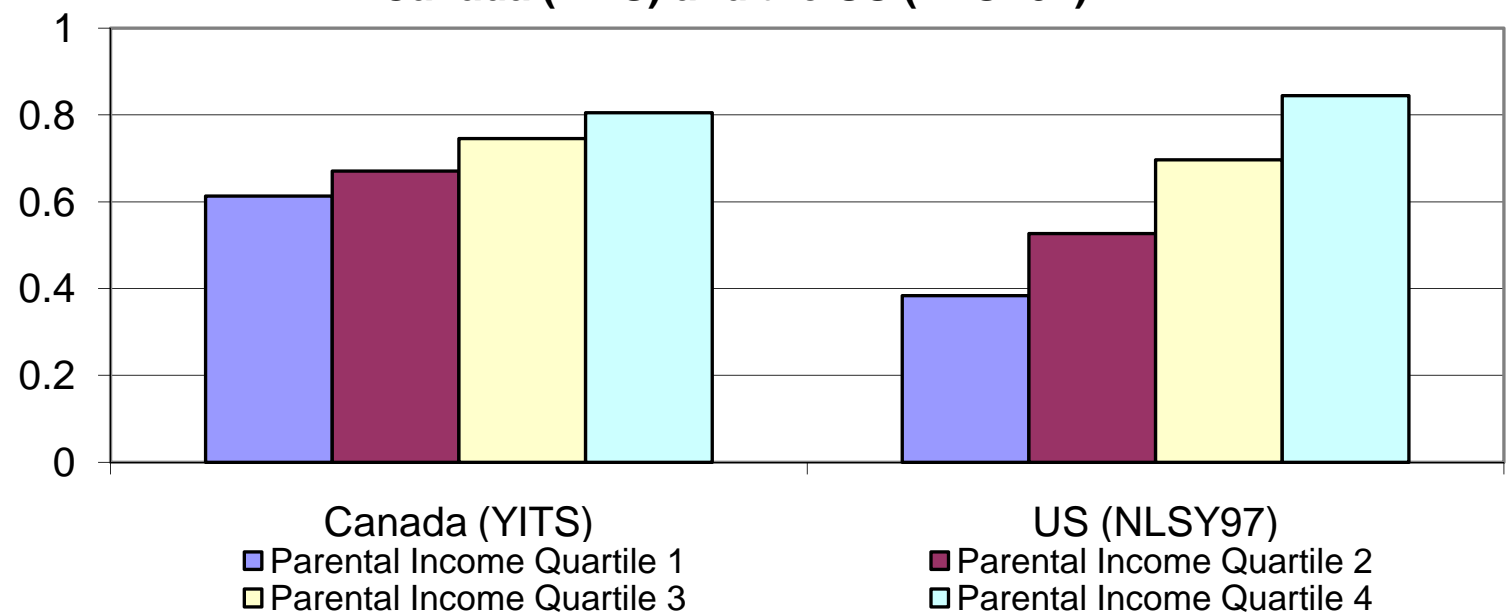

口Parental Income Quartile 1

口Parental Income Quartile 3

US (NLSY97)

口Parental Income Quartile 2

口Parental Income Quartile 4

Figure 2a: Post-Secondary Attendance by Math-Reading Ability and Parental Income Quartiles in Canada (YITS)

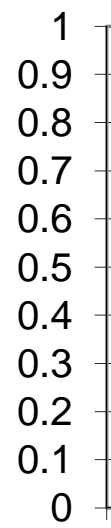

Ability Quartile 2 口Parental Income Quartile 1 口Parental Income Quartile 3
Ability Quartile 3 Ability Quartile 4 口Parental Income Quartile 2 口Parental Income Quartile 4

Figure 2b: Post-Secondary Attendance by Math-Reading Ability and Parental Income Quartiles in the US (NLSY97)

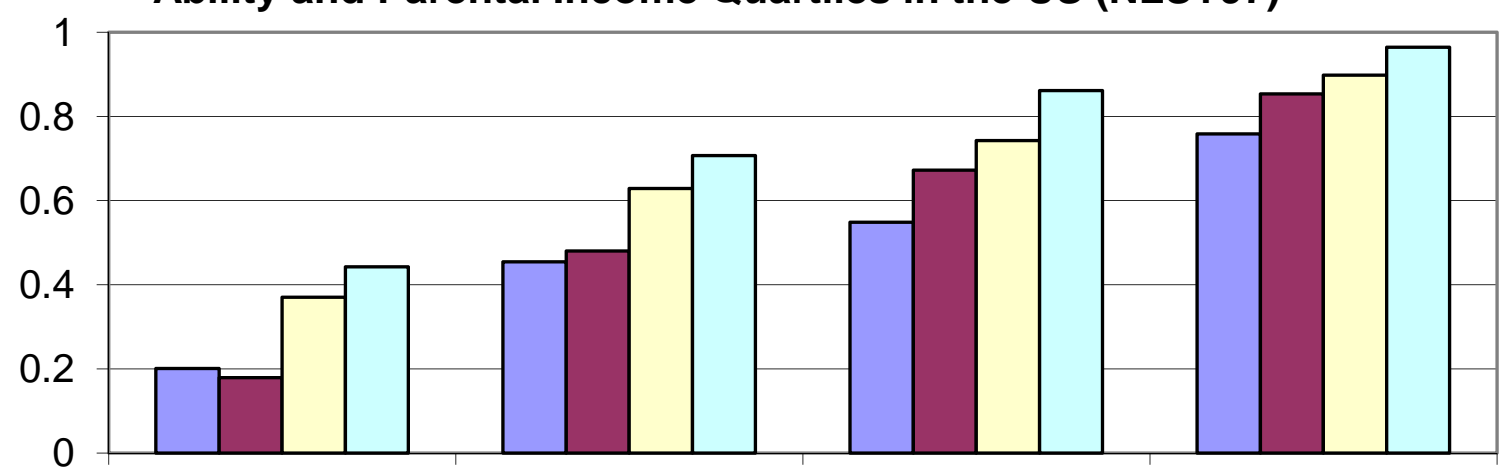

Ability Quartile 1 Ability Quartile 2 口Parental Income Quartile 1 口Parental Income Quartile 3
Ability Quartile $3 \quad$ Ability Quartile 4 口Parental Income Quartile 2 口Parental Income Quartile 4 
Figure 3a: Estimated Effects of Parental Income on Post-Secondary Attendance (Spline Function Estimates)

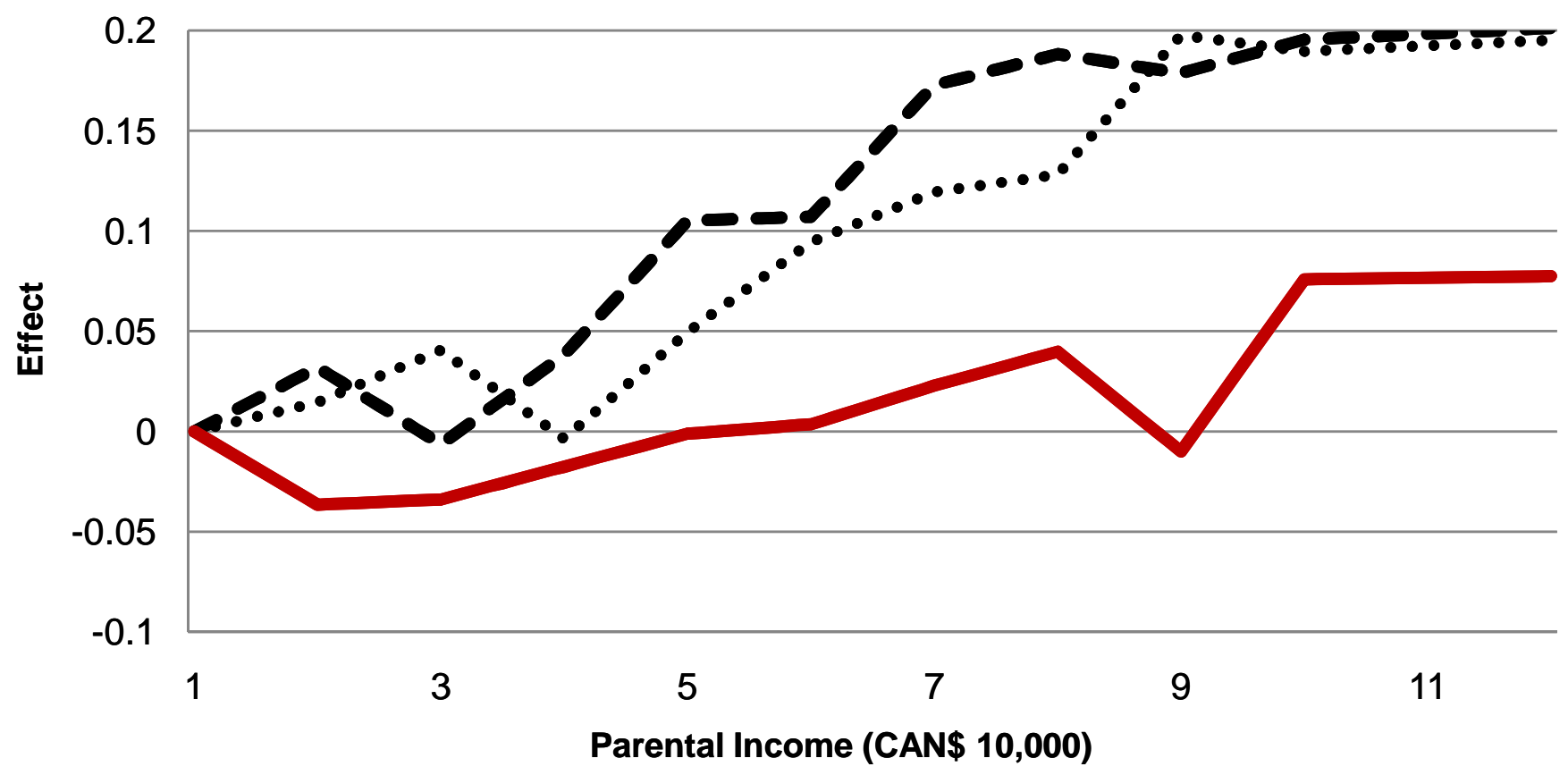

$\hookrightarrow$ NLSY97 (PPP Adjusted) $\quad \bullet \bullet N$ NSY97 (Exchange Rate Adjusted)

Figure 3b: Estimated Effects of Parental Income on Attendance at a Four-Year PS Institution (Spline Function Estimates)

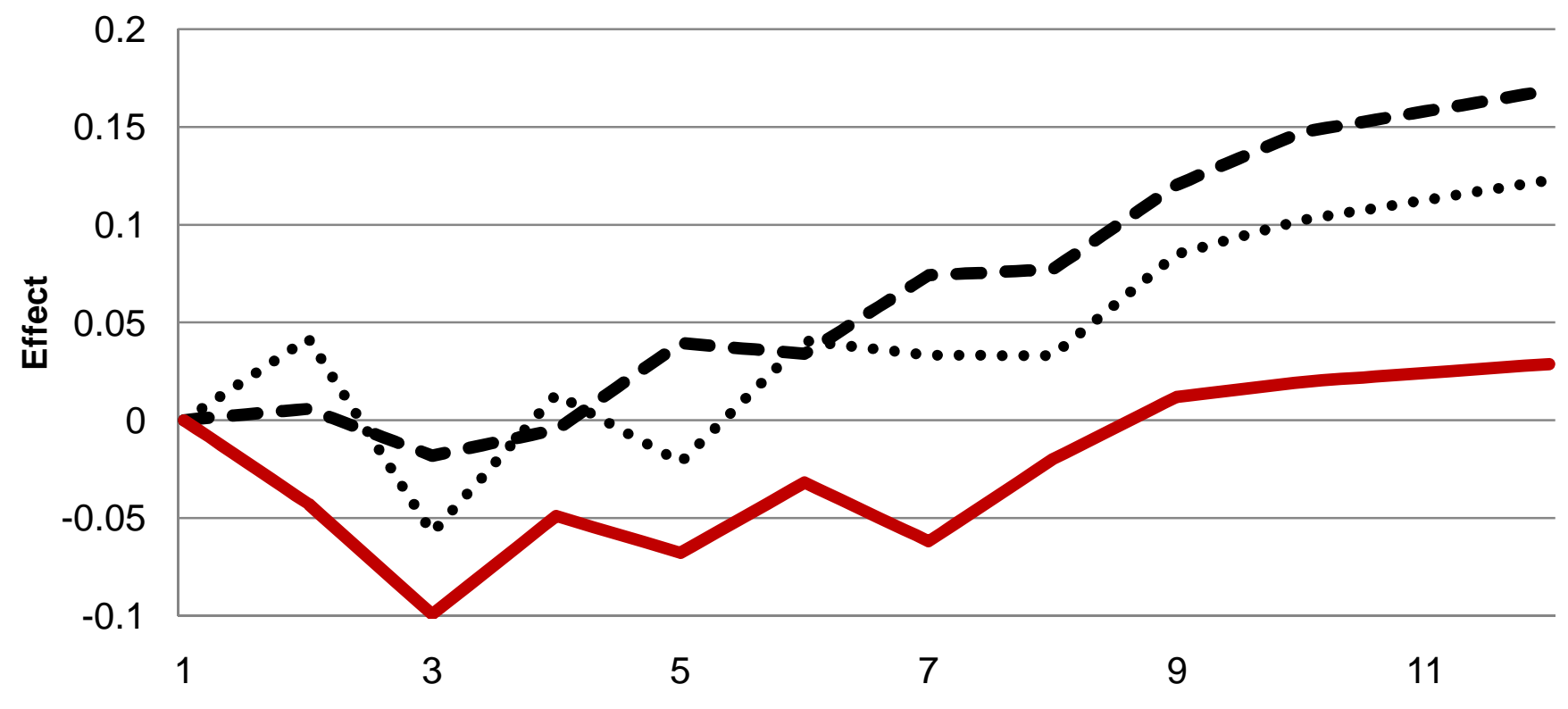

Parental Income (CAN\$ 10,000)

$\hookrightarrow$ NLSY97 (PPP Adjusted) • • NLSY97 (Exchange Rate Adjusted) 


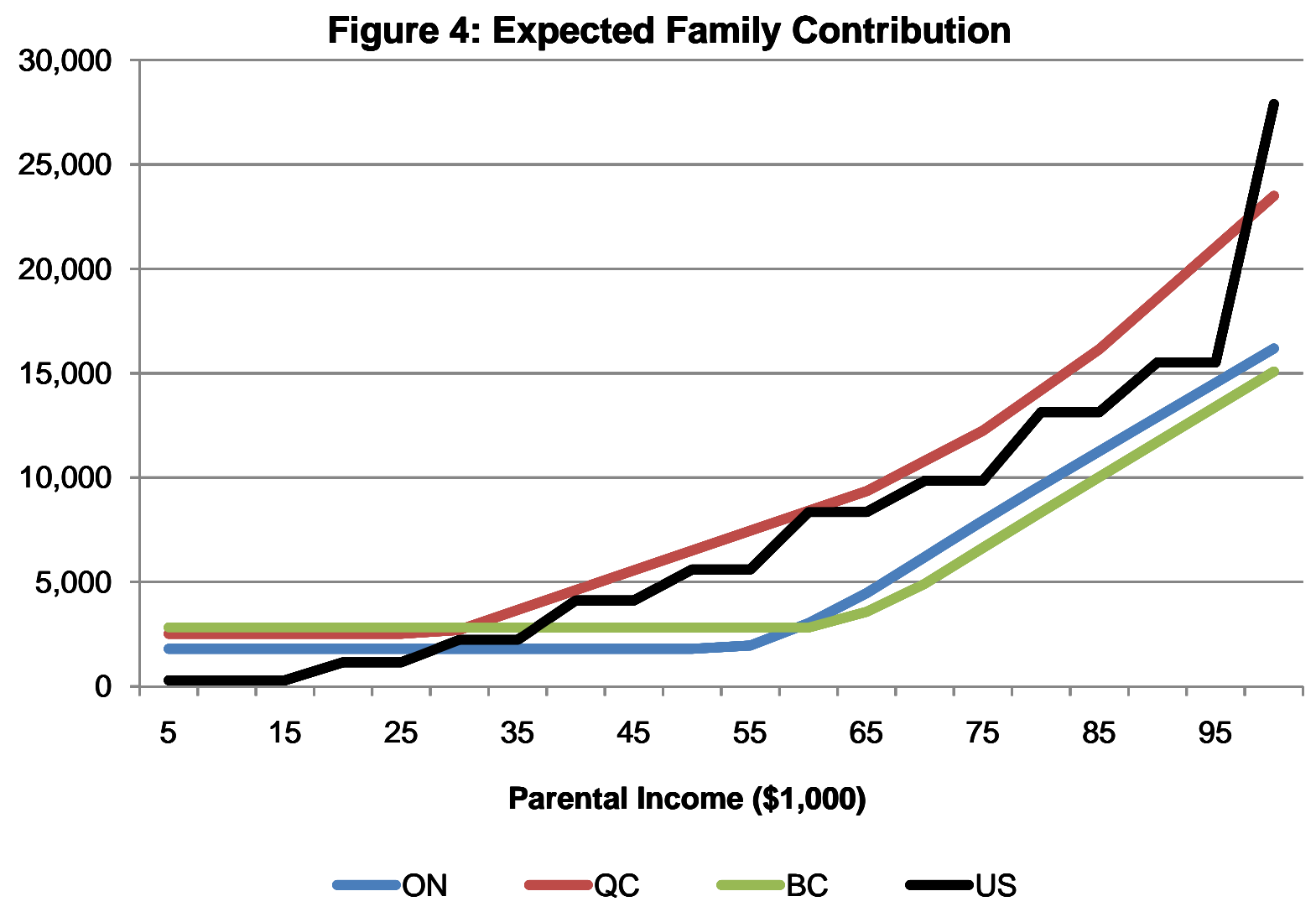

Figure 5: Total Non-Repayable Aid

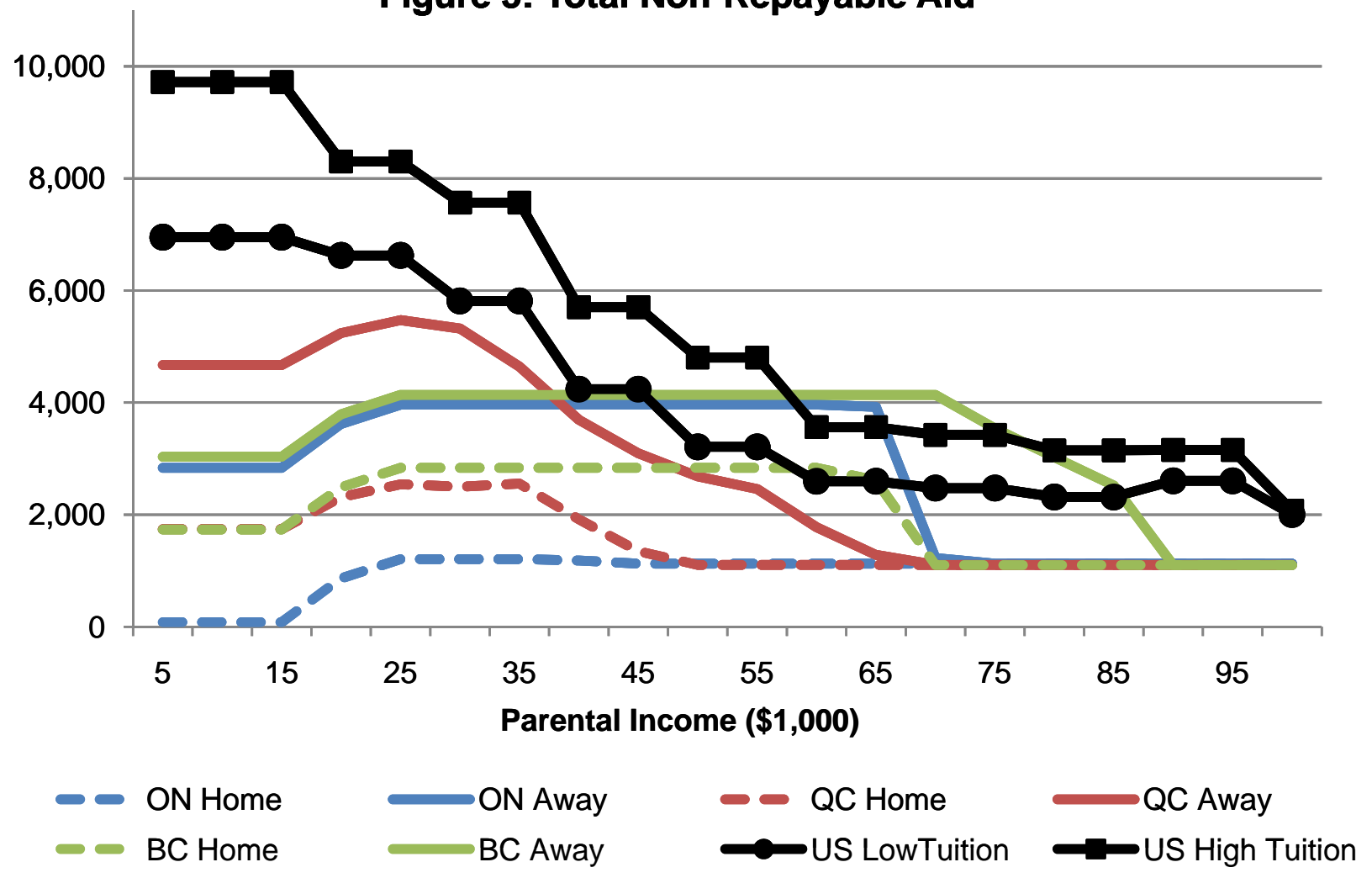


Figure 6: Total Available Government Loans

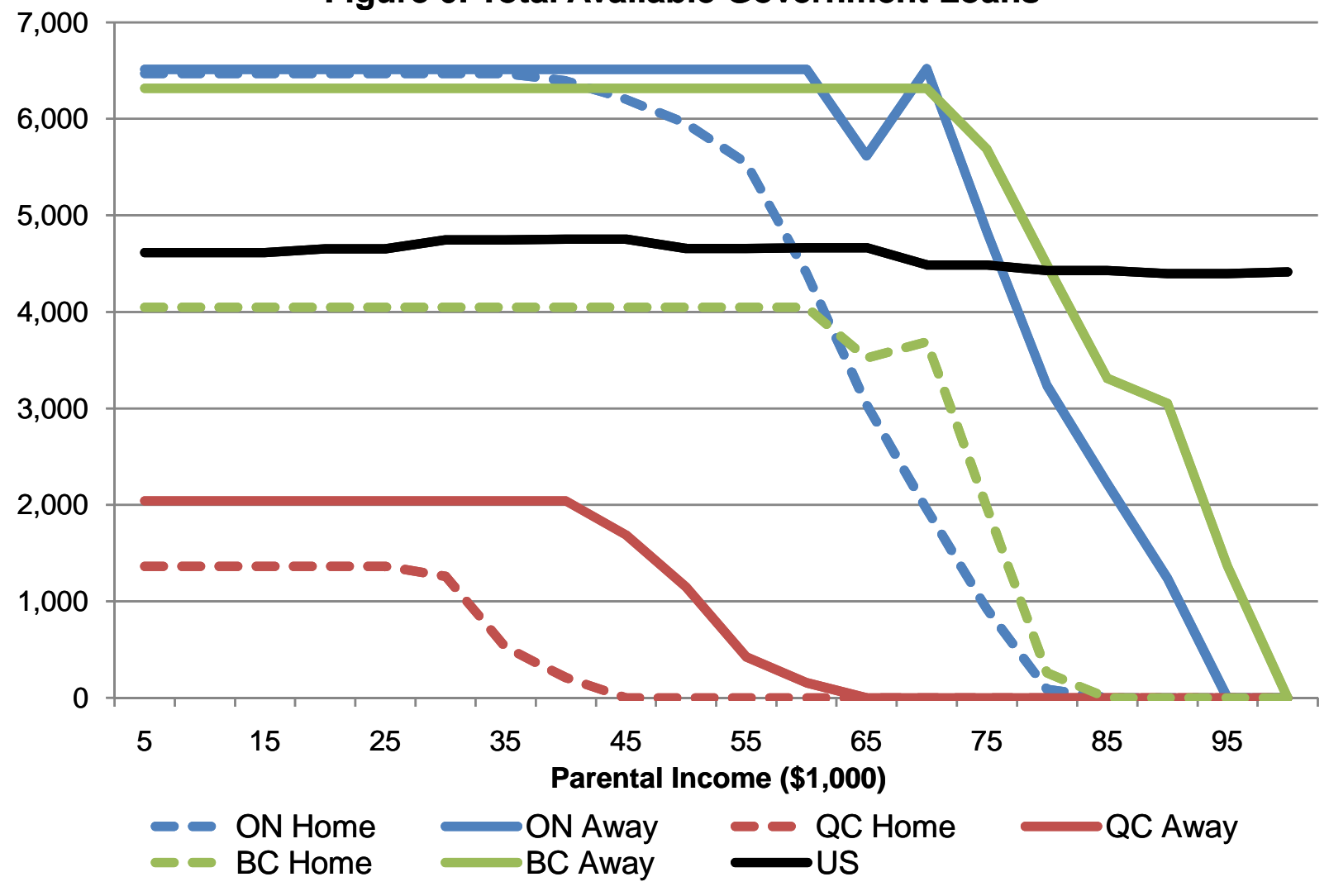

Figure 7: Net Tuition (Tuition less Non-Repayable Aid)

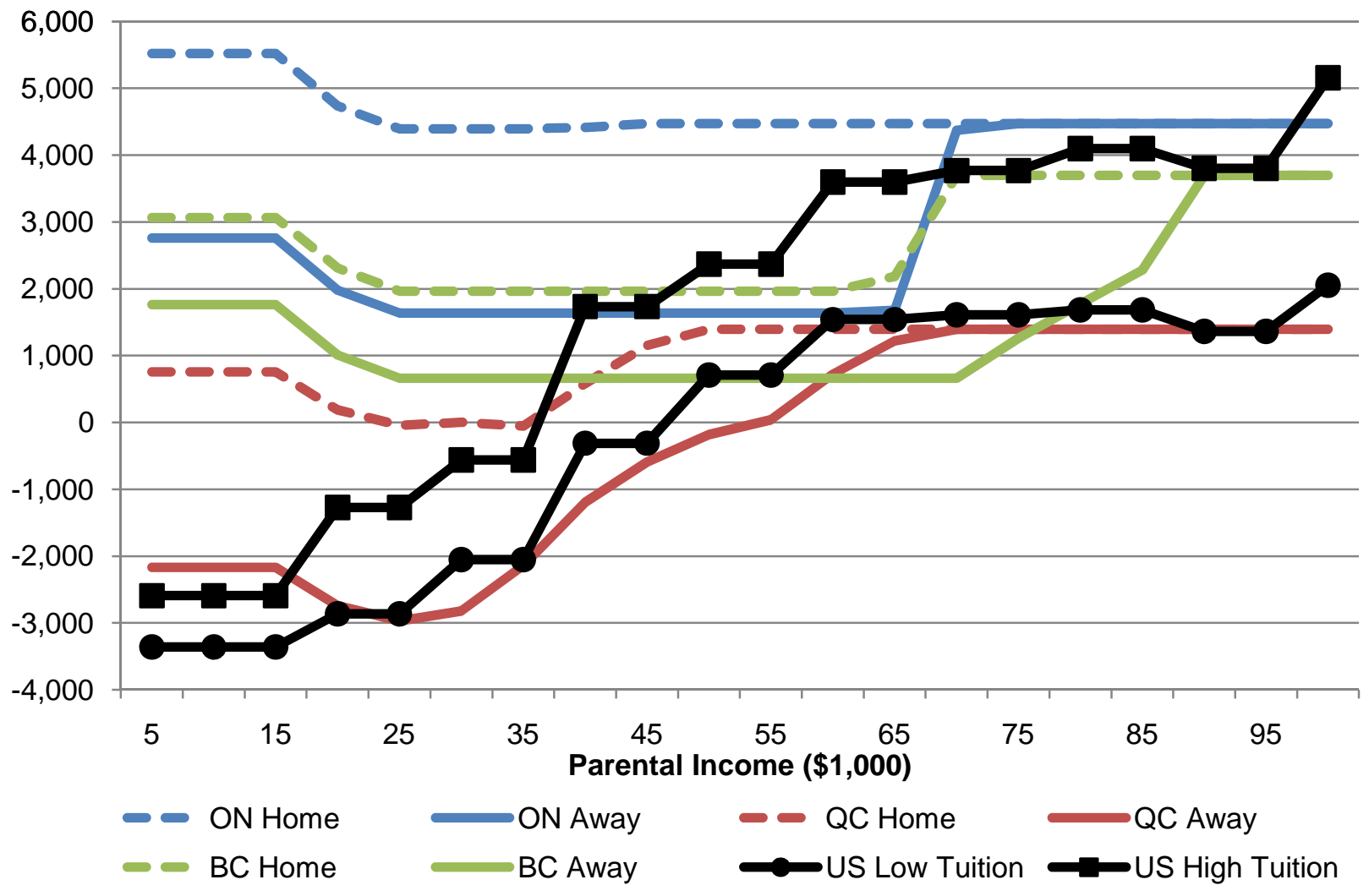


Figure 8: Out-of-Pocket Costs

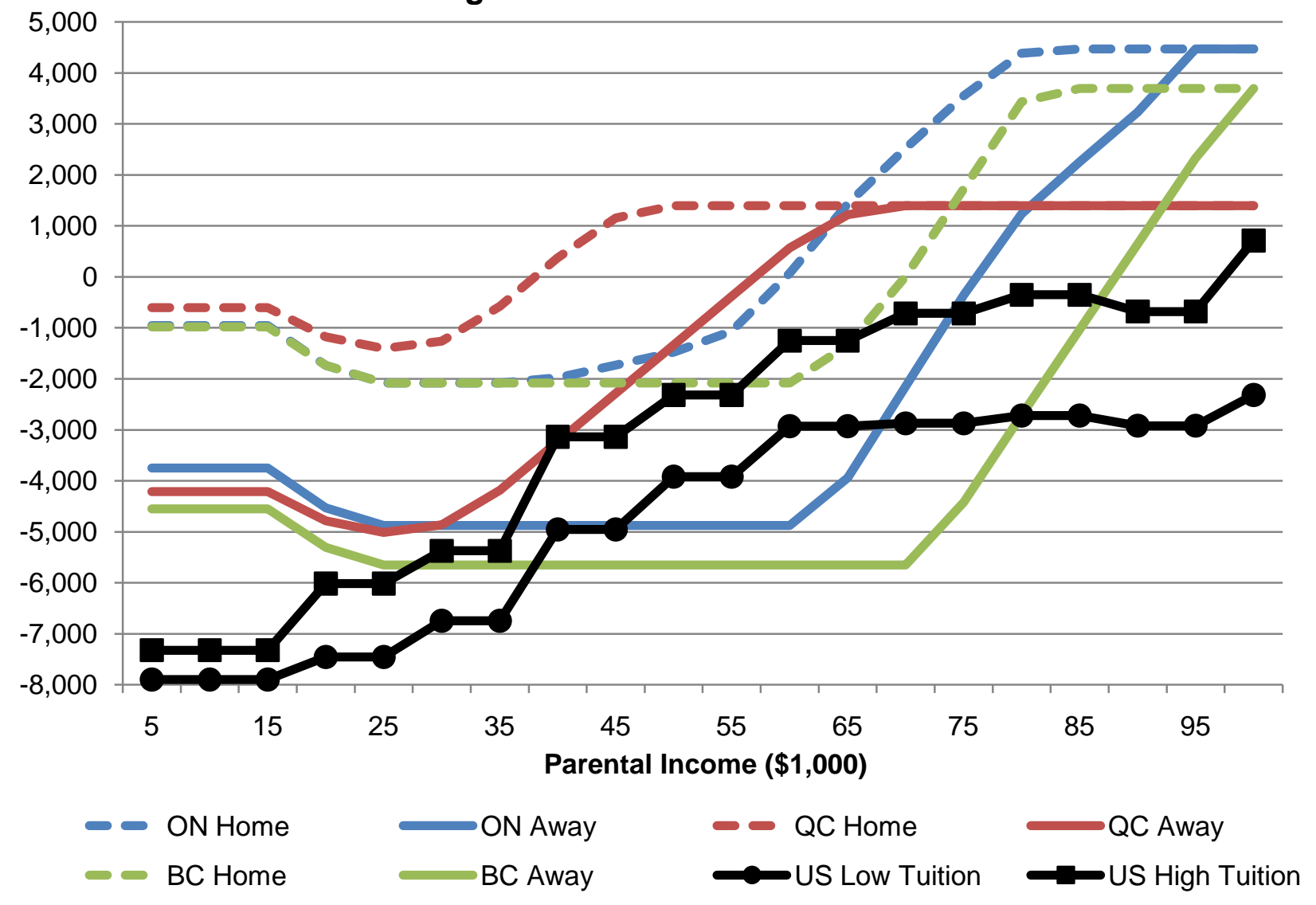


Figure 9: The Effect of 'Eliminating' Need-Based Non-Repayable Aid on PS

Attendance in the US and Canada

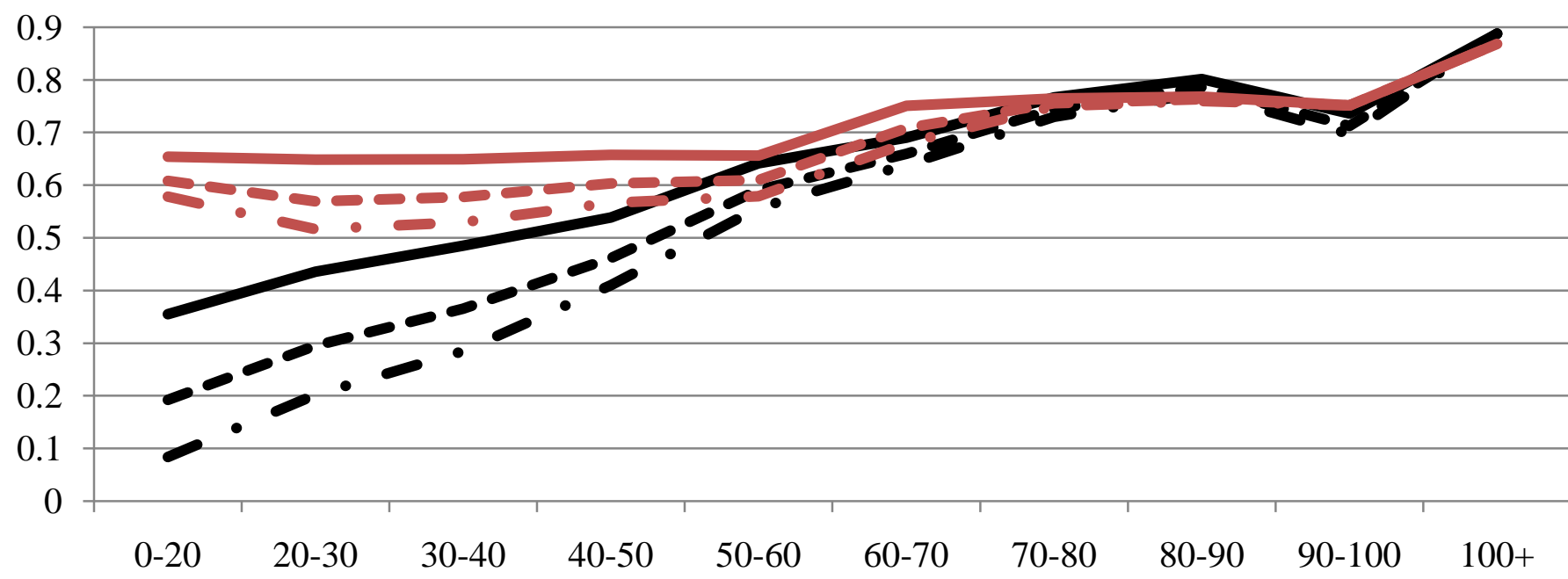

Parental Income Group $\mathbf{( \$ 1 , 0 0 0 )}$

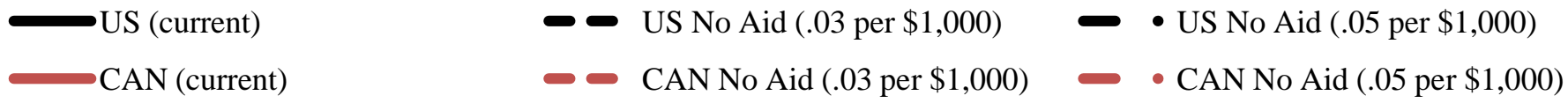

Figure 10: Non-Repayable Aid Required to Eliminate Conditional Family Income -- PS Attendance Gaps in the US and Canada

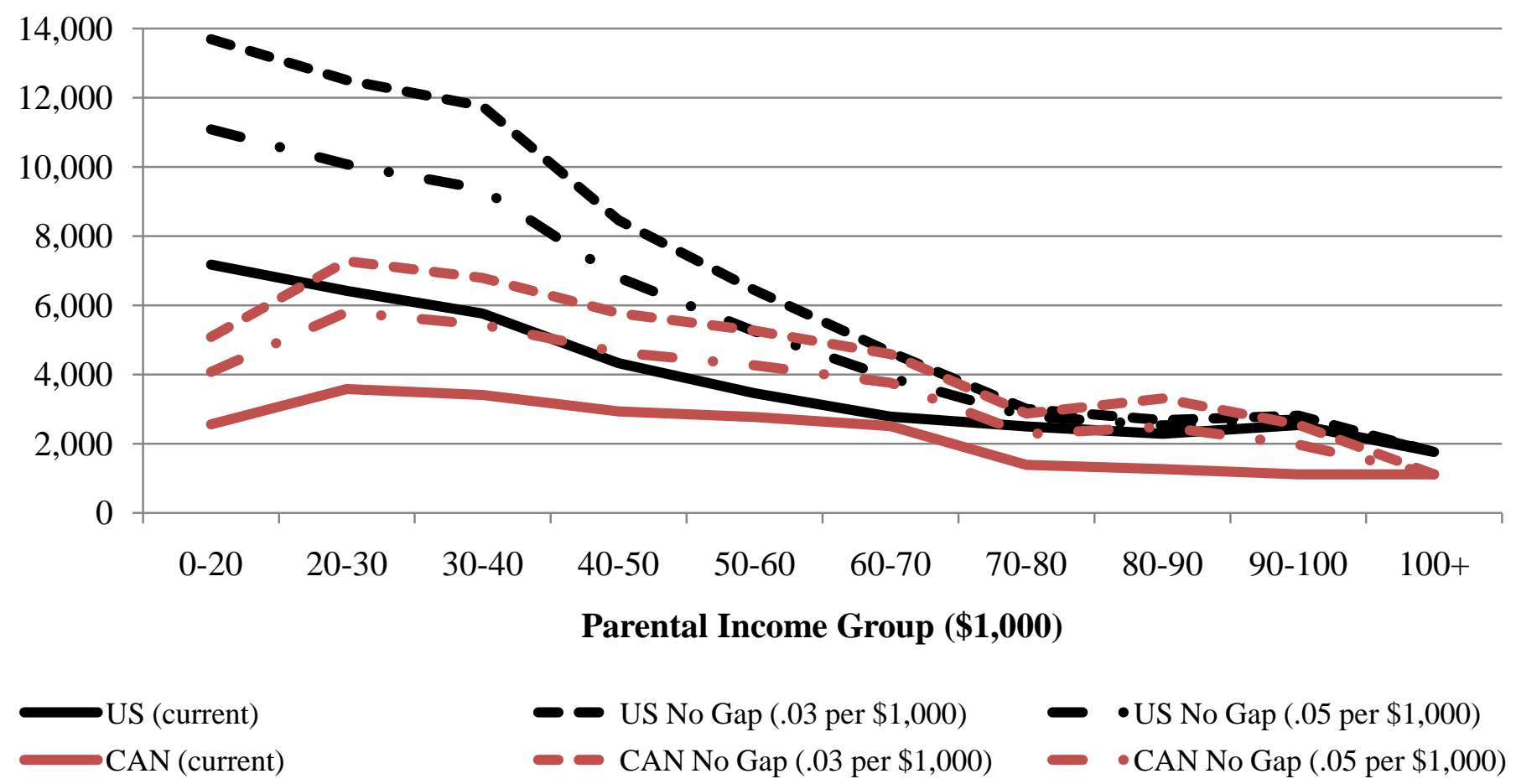


Table 1: Sample Descriptive Statistics

Canada (YITS)

Completed High School (as of age 21)

0.930

(0.255)

0.710

(0.454)

0.423

(0.494)

0.498

(0.500)

0.875

(0.331)

0.082

(0.275)

0.269

(0.444)

Mother's Age at Birth

28.170

(4.854)

0.754

(0.431)

0.679

(0.467)

1.472

(0.508)

0.887

(0.316)

0.594

(0.491)

7.174

(5.556)

2.814

(1.137)

5.481

(0.594)

7.552

(0.625)

12.660

(8.142)

US (NLSY97)

Average Parental Income (in \$10,000) in Quartile 2

Average Parental Income (in \$10,000) in Quartile 3

Average Parental Income (in \$10,000) in Quartile 4

9,031

0.832

(0.374)

0.625

$(0.484)$

0.420

(0.494)

0.506

(0.500)

0.695

(0.460)

0.033

(0.178)

0.126

(0.332)

25.991

(5.323)

0.563

(0.496)

0.790

(0.407)

2.329

(1.147)

0.847

(0.360)

0.493

(0.500)

6.422

(4.773)

1.561

(0.749)

4.026

(0.716)

6.609

(0.889)

12.572

(4.638)

4,108

Sample Size

Note: Table reports means with standard deviations in parentheses. YITS sample includes individuals with non-missing reading and mathematics scores and parental income. NLSY97 sample includes individuals with non-missing reading and mathematics scores and parental income measured in 1997 if they had reached age 21 by 2005. All dollar values denominated in year 1999 dollars. U.S. incomes adjusted by PPP = 1.19. 
Table 2: Effects of Family Income, Math-Reading Achievement, and Family Background on Educa

\begin{tabular}{|c|c|c|c|c|}
\hline & PS A & dance & $\begin{array}{r}\text { Attendance } \\
\text { PS II }\end{array}$ & $\begin{array}{l}\text { Four-Year } \\
\text { ution }\end{array}$ \\
\hline & YITS & NLSY97 & YITS & NLSY97 \\
\hline Male & $\begin{array}{c}-0.1272 \\
(0.0086)\end{array}$ & $\begin{array}{c}-0.0927 \\
(0.0130)\end{array}$ & $\begin{array}{c}-0.1478 \\
(0.0089)\end{array}$ & $\begin{array}{c}-0.0895 \\
(0.0134)\end{array}$ \\
\hline Immigrant & $\begin{array}{c}0.0812 \\
(0.0179)\end{array}$ & $\begin{array}{c}0.1574 \\
(0.0444)\end{array}$ & $\begin{array}{c}0.0938 \\
(0.0186)\end{array}$ & $\begin{array}{c}0.1507 \\
(0.0456)\end{array}$ \\
\hline At Least One Parent an Immigrant & $\begin{array}{c}0.0790 \\
(0.0113)\end{array}$ & $\begin{array}{c}0.0521 \\
(0.0242)\end{array}$ & $\begin{array}{c}0.1139 \\
(0.0117)\end{array}$ & $\begin{array}{c}0.0178 \\
(0.0248)\end{array}$ \\
\hline Mother's Age at Birth & $\begin{array}{c}0.0070 \\
(0.0010)\end{array}$ & $\begin{array}{c}0.0031 \\
(0.0014)\end{array}$ & $\begin{array}{c}0.0061 \\
(0.0010)\end{array}$ & $\begin{array}{c}0.0039 \\
(0.0014)\end{array}$ \\
\hline Intact Family during Adolescence & $\begin{array}{c}0.0538 \\
(0.0106)\end{array}$ & $\begin{array}{c}0.0793 \\
(0.0150)\end{array}$ & $\begin{array}{c}0.0560 \\
(0.0110)\end{array}$ & $\begin{array}{c}0.0960 \\
(0.0154)\end{array}$ \\
\hline Metropolitan Area during Adolescence & $\begin{array}{c}0.0339 \\
(0.0097)\end{array}$ & $\begin{array}{c}0.0139 \\
(0.0163)\end{array}$ & $\begin{array}{c}0.0351 \\
(0.0101)\end{array}$ & $\begin{array}{c}0.0034 \\
(0.0167)\end{array}$ \\
\hline Number of Children under 18 & $\begin{array}{c}0.0227 \\
(0.0089)\end{array}$ & $\begin{array}{c}-0.0089 \\
(0.0062)\end{array}$ & $\begin{array}{c}0.0400 \\
(0.0093)\end{array}$ & $\begin{array}{c}-0.0028 \\
(0.0064)\end{array}$ \\
\hline Mother HS Graduate & $\begin{array}{c}0.1123 \\
(0.0152)\end{array}$ & $\begin{array}{c}0.0898 \\
(0.0209)\end{array}$ & $\begin{array}{c}0.0740 \\
(0.0158)\end{array}$ & $\begin{array}{c}0.0222 \\
(0.0214)\end{array}$ \\
\hline Mother at Least Some PSE & $\begin{array}{c}0.0578 \\
(0.0100)\end{array}$ & $\begin{array}{c}0.0756 \\
(0.0150)\end{array}$ & $\begin{array}{c}0.0774 \\
(0.0104)\end{array}$ & $\begin{array}{c}0.1151 \\
(0.0154)\end{array}$ \\
\hline Math-Reading Achievement Quartile 2 & $\begin{array}{c}0.1997 \\
(0.0122)\end{array}$ & $\begin{array}{c}0.2509 \\
(0.0197)\end{array}$ & $\begin{array}{c}0.1671 \\
(0.0126)\end{array}$ & $\begin{array}{c}0.1293 \\
(0.0202)\end{array}$ \\
\hline Math-Reading Achievement Quartile 3 & $\begin{array}{c}0.2988 \\
(0.0124)\end{array}$ & $\begin{array}{c}0.3945 \\
(0.0203)\end{array}$ & $\begin{array}{c}0.3139 \\
(0.0128)\end{array}$ & $\begin{array}{c}0.3239 \\
(0.0208)\end{array}$ \\
\hline Math-Reading Achievement Quartile 4 & $\begin{array}{c}0.3714 \\
(0.0126)\end{array}$ & $\begin{array}{c}0.5201 \\
(0.0211)\end{array}$ & $\begin{array}{c}0.5215 \\
(0.0131)\end{array}$ & $\begin{array}{c}0.5585 \\
(0.0217)\end{array}$ \\
\hline Parental Income Quartile 2 & $\begin{array}{c}0.0201 \\
(0.0126)\end{array}$ & $\begin{array}{c}0.0290 \\
(0.0200)\end{array}$ & $\begin{array}{c}-0.0005 \\
(0.0131)\end{array}$ & $\begin{array}{c}0.0118 \\
(0.0205)\end{array}$ \\
\hline Parental Income Quartile 3 & $\begin{array}{c}0.0450 \\
(0.0130)\end{array}$ & $\begin{array}{c}0.1232 \\
(0.0213)\end{array}$ & $\begin{array}{c}0.0193 \\
(0.0135)\end{array}$ & $\begin{array}{c}0.0547 \\
(0.0218)\end{array}$ \\
\hline Parental Income Quartile 4 & $\begin{array}{c}0.0693 \\
(0.0132)\end{array}$ & $\begin{array}{c}0.1762 \\
(0.0228)\end{array}$ & $\begin{array}{c}0.0794 \\
(0.0138)\end{array}$ & $\begin{array}{c}0.1645 \\
(0.0234)\end{array}$ \\
\hline Test of no Income Effects (P-value) & $<.0001$ & $<.0001$ & $<.0001$ & $<.0001$ \\
\hline Sample Size & 9,028 & 3,812 & 9,028 & 3,700 \\
\hline
\end{tabular}

Notes: Education measured as of age 21. NLSY97 regressions also control for year of birth and race/hispanic ethnicity indicators. Test of no Income Effects is an F-test (3 d.o.f.) that all three coefficients on family income are zero. Standard errors are in parentheses. 
Table 3: Effects of Parental Income on Educational Attainment at Age 21 by Math-Reading Ability Quartile

\begin{tabular}{|c|c|c|c|c|c|c|c|c|}
\hline & \multicolumn{4}{|c|}{ Post-Secondary Attendance: } & \multicolumn{4}{|c|}{ Attendance at a 4-Year Post-Secondary Institution } \\
\hline & $\begin{array}{c}\text { Achieve. } \\
\text { Quartile 1 } \\
\end{array}$ & $\begin{array}{c}\text { Achieve. } \\
\text { Quartile } 2 \\
\end{array}$ & $\begin{array}{c}\text { Achieve. } \\
\text { Quartile } 3 \\
\end{array}$ & $\begin{array}{c}\text { Achieve. } \\
\text { Quartile } 4 \\
\end{array}$ & $\begin{array}{c}\text { Achieve. } \\
\text { Quartile 1 } \\
\end{array}$ & $\begin{array}{c}\text { Achieve. } \\
\text { Quartile } 2 \\
\end{array}$ & $\begin{array}{c}\text { Achieve. } \\
\text { Quartile } 3 \\
\end{array}$ & $\begin{array}{c}\text { Achieve. } \\
\text { Quartile } 4 \\
\end{array}$ \\
\hline \multicolumn{9}{|l|}{ a. YITS } \\
\hline Parental Income Quartile 2 & $\begin{array}{c}0.0132 \\
(0.0269)\end{array}$ & $\begin{array}{c}0.0485 \\
(0.0262)\end{array}$ & $\begin{array}{l}-0.0313 \\
(0.0251)\end{array}$ & $\begin{array}{c}0.0471 \\
(0.0208)\end{array}$ & $\begin{array}{c}0.0219 \\
(0.0189)\end{array}$ & $\begin{array}{c}-0.0048 \\
(0.0260)\end{array}$ & $\begin{array}{l}-0.0108 \\
(0.0310)\end{array}$ & $\begin{array}{l}-0.0041 \\
(0.0300)\end{array}$ \\
\hline Parental Income Quartile 3 & $\begin{array}{c}0.0286 \\
(0.0294)\end{array}$ & $\begin{array}{c}0.0777 \\
(0.0272)\end{array}$ & $\begin{array}{c}-0.0055 \\
(0.0252)\end{array}$ & $\begin{array}{c}0.0683 \\
(0.0205)\end{array}$ & $\begin{array}{c}0.0163 \\
(0.0207)\end{array}$ & $\begin{array}{c}0.0573 \\
(0.0270)\end{array}$ & $\begin{array}{l}-0.0183 \\
(0.0311)\end{array}$ & $\begin{array}{c}0.0276 \\
(0.0295)\end{array}$ \\
\hline Parental Income Quartile 4 & $\begin{array}{c}0.1462 \\
(0.0315)\end{array}$ & $\begin{array}{c}0.0809 \\
(0.0282)\end{array}$ & $\begin{array}{c}0.0283 \\
(0.0253)\end{array}$ & $\begin{array}{c}0.0448 \\
(0.0202)\end{array}$ & $\begin{array}{c}0.0960 \\
(0.0221)\end{array}$ & $\begin{array}{c}0.0757 \\
(0.0280)\end{array}$ & $\begin{array}{c}0.0799 \\
(0.0313)\end{array}$ & $\begin{array}{c}0.0571 \\
(0.0292)\end{array}$ \\
\hline Test of no Income Effects (P-value) & $<.0001$ & 0.0129 & 0.0838 & 0.0107 & 0.0001 & 0.0052 & 0.0014 & 0.0675 \\
\hline Sample Size & 2,217 & 2,358 & 2,227 & 2,226 & 2,217 & 2,358 & 2,227 & 2,226 \\
\hline \multicolumn{9}{|l|}{ b. NLSY97 } \\
\hline Parental Income Quartile 2 & $\begin{array}{l}-0.0556 \\
(0.0368)\end{array}$ & $\begin{array}{c}0.0472 \\
(0.0450)\end{array}$ & $\begin{array}{c}0.0888 \\
(0.0448)\end{array}$ & $\begin{array}{c}0.0544 \\
(0.0371)\end{array}$ & $\begin{array}{l}-0.0052 \\
(0.0259)\end{array}$ & $\begin{array}{c}0.0541 \\
(0.0408)\end{array}$ & $\begin{array}{c}0.0127 \\
(0.0518)\end{array}$ & $\begin{array}{c}0.0386 \\
(0.0519)\end{array}$ \\
\hline Parental Income Quartile 3 & $\begin{array}{c}0.1631 \\
(0.0437)\end{array}$ & $\begin{array}{c}0.1574 \\
(0.0472)\end{array}$ & $\begin{array}{c}0.1030 \\
(0.0456)\end{array}$ & $\begin{array}{c}0.0878 \\
(0.0368)\end{array}$ & $\begin{array}{c}0.0442 \\
(0.0308)\end{array}$ & $\begin{array}{c}0.1105 \\
(0.0428)\end{array}$ & $\begin{array}{c}0.0174 \\
(0.0528)\end{array}$ & $\begin{array}{c}0.0585 \\
(0.0517)\end{array}$ \\
\hline Parental Income Quartile 4 & $\begin{array}{c}0.2020 \\
(0.0577)\end{array}$ & $\begin{array}{c}0.2004 \\
(0.0515)\end{array}$ & $\begin{array}{c}0.2140 \\
(0.0473)\end{array}$ & $\begin{array}{c}0.1294 \\
(0.0371)\end{array}$ & $\begin{array}{c}0.1139 \\
(0.0408)\end{array}$ & $\begin{array}{c}0.2288 \\
(0.0471)\end{array}$ & $\begin{array}{c}0.1392 \\
(0.0546)\end{array}$ & $\begin{array}{c}0.1528 \\
(0.0520)\end{array}$ \\
\hline Test of no Income Effects (P-value) & $<.0001$ & 0.0001 & $<.0001$ & 0.0014 & 0.0158 & $<.0001$ & 0.0061 & 0.0010 \\
\hline Sample Size & 845 & 933 & 973 & 1061 & 831 & 918 & 957 & 994 \\
\hline
\end{tabular}

Notes: All regressions control for gender, race/ethnicity (NLSY97 only), immigrant status, whether at least one parent is an immigrant, mother's education (HS graduate, PS attendance), intact family during adolescence, number of children under 18, mother's age at child's birth, metropolitan area during adolescence, and year of birth (NLSY97 only). Education measured as of age 21. Test of no Income Effects is an F-test (3 d.o.f.) that all three coefficients on family income are zero. Standard errors are in parentheses. 
Table 4a: Educational Attainment in Canada: Quebec vs. Other Provinces (YITS)

\begin{tabular}{lcccc} 
& \multicolumn{2}{c}{ PS Attendance: } & \multicolumn{2}{c}{$\begin{array}{c}\text { Attendance at a 4-Year } \\
\text { PS Institution: }\end{array}$} \\
& Quebec & Other Provinces & Quebec & Other Provinces \\
\hline Math-Reading Achievement Quartile 2 & 0.3408 & 0.1739 & 0.0825 & 0.2009 \\
& $(0.0330)$ & $(0.0130)$ & $(0.0329)$ & $(0.0135)$ \\
Math-Reading Achievement Quartile 3 & 0.4864 & 0.2578 & 0.2291 & 0.3555 \\
& $(0.0326)$ & $(0.0134)$ & $(0.0326)$ & $(0.0139)$ \\
Math-Reading Achievement Quartile 4 & 0.5887 & 0.3214 & 0.5128 & 0.5424 \\
& $(0.0331)$ & $(0.0136)$ & $(0.0331)$ & $(0.0142)$ \\
Parental Income Quartile 2 & -0.0145 & 0.0268 & -0.0129 & 0.0019 \\
Parental Income Quartile 3 & $(0.0293)$ & $(0.0140)$ & $(0.0293)$ & $(0.0146)$ \\
Parental Income Quartile 4 & 0.0592 & 0.0358 & 0.0204 & 0.0063 \\
& $(0.0322)$ & $(0.0142)$ & $(0.0322)$ & $(0.0148)$ \\
Test of no Income Effects (P-value) & 0.0314 & 0.0725 & 0.0982 & 0.0576 \\
Sample Size & $(0.0341)$ & $(0.0144)$ & $(0.0341)$ & $(0.0150)$ \\
\hline
\end{tabular}

Notes: All regressions control for gender, immigrant status, whether at least one parent is an immigrant, mother's education (HS graduate, PS attendance), intact family during adolescence, number of children under 18, mother's age at child's birth, and metropolitan area during adolescence. Education measured as of age 21. Test of no Income Effects is an F-test (3 d.o.f.) that all three coefficients on family income are zero. Standard errors are in parentheses. 
Table 4b: Educational Attainment in High and Low Tuition U.S. States (NLSY97)

Attendance at a 4-Year

PS Attendance:

PS Institution:

Low Tuition High Tuition

Low Tuition High Tuition

\begin{tabular}{lcccc} 
Math-Reading Achievement Quartile 2 & 0.2789 & 0.2225 & 0.1443 & 0.1157 \\
& $(0.0280)$ & $(0.0278)$ & $(0.0285)$ & $(0.0286)$ \\
Math-Reading Achievement Quartile 3 & 0.4127 & 0.3753 & 0.3154 & 0.3281 \\
& $(0.0292)$ & $(0.0283)$ & $(0.0298)$ & $(0.0291)$ \\
Math-Reading Achievement Quartile 4 & 0.5246 & 0.5111 & 0.5395 & 0.5396 \\
& $(0.0305)$ & $(0.0293)$ & $(0.0312)$ & $(0.0303)$ \\
Parental Income Quartile 2 & 0.0180 & 0.0512 & 0.0107 & 0.0181 \\
Parental Income Quartile 3 & $(0.0283)$ & $(0.0285)$ & $(0.0288)$ & $(0.0292)$ \\
Parental Income Quartile 4 & 0.0751 & 0.1746 & 0.0580 & 0.0546 \\
& $(0.0308)$ & $(0.0297)$ & $(0.0314)$ & $(0.0305)$ \\
Test of no Income Effects (P-value) & 0.1486 & 0.2146 & 0.1841 & 0.1507 \\
Sample Size & $(0.0326)$ & $(0.0321)$ & $(0.0333)$ & $(0.0331)$ \\
\hline
\end{tabular}

Notes: All regressions control for gender, immigrant status, whether at least one parent is an immigrant, mother's education (HS graduate, PS attendance), intact family during adolescence, number of children under 18, mother's age at child's birth, and metropolitan area during adolescence. Education measured as of age 21. Test of no Income Effects is an F-test (3 d.o.f.) that all three coefficients on family income are zero. Standard errors are in parentheses. 
Table A1: Additional Specifications for Post-Secondary Attendance in Canada (YITS)

(i)

(ii)

(iii)

(iv)

White English-

Speaking Native

Youth with

Native Parents

\begin{tabular}{|c|c|c|}
\hline & Contr & \\
\hline $\begin{array}{r}\text { Contro } \\
\text { School } \\
\text { Effe }\end{array}$ & $\begin{array}{c}\text { Perceived Returns } \\
\text { to School \& Peers' } \\
\text { PS Plans }\end{array}$ & $\begin{array}{l}\text { PS Attendance } \\
\text { Conditional on } \\
\text { Graduating HS }\end{array}$ \\
\hline
\end{tabular}

\begin{tabular}{lcccc} 
Math-Reading Achievement Quartile 2 & 0.1803 & 0.2080 & 0.1813 & 0.1626 \\
& $(0.0158)$ & $(0.0209)$ & $(0.0121)$ & $(0.0125)$ \\
Math-Reading Achievement Quartile 3 & 0.2793 & 0.3079 & 0.2729 & 0.2412 \\
& $(0.0162)$ & $(0.0202)$ & $(0.0124)$ & $(0.0126)$ \\
Math-Reading Achievement Quartile 4 & 0.3437 & 0.3874 & 0.3362 & 0.3078 \\
& $(0.0167)$ & $(0.0198)$ & $(0.0128)$ & $(0.0127)$ \\
Parental Income Quartile 2 & 0.0566 & 0.0232 & 0.0198 & 0.0291 \\
Parental Income Quartile 3 & $(0.0172)$ & $(0.0190)$ & $(0.0125)$ & $(0.0128)$ \\
Parental Income Quartile 4 & 0.0717 & 0.0420 & 0.0408 & 0.0428 \\
& $(0.0173)$ & $(0.0196)$ & $(0.0129)$ & $(0.0130)$ \\
Test of no Income Effects (P-value) & 0.1152 & 0.0456 & 0.0609 & 0.0655 \\
Sample Size & $(0.0176)$ & $(0.0203)$ & $(0.0131)$ & $(0.0132)$ \\
\hline
\end{tabular}

Notes: Regressions control for gender, immigrant status, whether at least one parent is an immigrant, mother's education (HS graduate, PS attendance), intact family during adolescence, number of children under 18, mother's age at child's birth, and metropolitan area during adolescence. The dependent variable for all specifications is PS attendance measured as of age 21. Sample for column (i) only includes native-born whites with native parents whose native tongue is English. Column (ii) controls for school fixed effects. Column (iii) controls for three indicators measuring level of perceived returns to education and two indicators for whether most or all peers plan to attend PS schooling (see text for details). Sample for column (iv) includes only those who completed high school. Test of no Income Effects is an F-test (3 d.o.f.) that all three coefficients on family income are zero. Standard errors are in parentheses. 
Table A2: Additional Specifications for Post-Secondary Attendance in the U.S. (NLSY97)

(i)

(ii)

(iii)

\begin{tabular}{|c|c|c|}
\hline & Controls for & \\
\hline $\begin{array}{l}\text { White Native } \\
\text { Youth with } \\
\text { Native Parents }\end{array}$ & $\begin{array}{c}\text { County x MSA } \\
\text { Residential Status } \\
\text { Fixed Effects }\end{array}$ & $\begin{array}{l}\text { PS Attendance } \\
\text { Conditional on } \\
\text { Graduating HS }\end{array}$ \\
\hline
\end{tabular}

Math-Reading Achievement Quartile 2

0.2550

0.2546

0.2202

(0.0256)

(0.0207)

(0.0227)

Math-Reading Achievement Quartile 3

0.4037

0.3935

0.3468

(0.0254)

(0.0214)

$(0.0227)$

Math-Reading Achievement Quartile 4

0.5429

0.5178

0.4377

(0.0256)

(0.0223)

$(0.0231)$

Parental Income Quartile 2

0.0665

0.0302

0.0226

(0.0262)

(0.0218)

(0.0228)

Parental Income Quartile 3

0.1632

0.1242

0.0957

(0.0266)

(0.0233)

(0.0234)

Parental Income Quartile 4

0.2178

0.1731

0.1290

(0.0282)

(0.0253)

(0.0245)

Test of no Income Effects (P-value)

$<.0001$

$<.0001$

$<.0001$

Sample Size

2,537

3,797

3,180

Notes: Regressions control for gender, race/ethnicity, immigrant status, whether at least one parent is an immigrant, mother's education (HS graduate, PS attendance), intact family during adolescence, number of children under 18, mother's age at child's birth, metropolitan area during adolescence, and year of birth. The dependent variable for all specifications is PS attendance measured as of age 21. Sample for column (i) only includes native-born whites with native parents. Column (ii) controls for school fixed effects. Sample for column (iv) includes only those who completed high school. Test of no Income Effects is an F-test (3 d.o.f.) that all three coefficients on family income are zero. Standard errors are in parentheses. 
Table A3: Effects of Family Income and Achievement on Post-Secondary Attendance by Area of Residence in the U.S. (NLSY97)

(i)

(ii)

(iii)

(iv)

(v)

(vi)

(vii)

\begin{tabular}{|c|c|c|c|c|c|c|c|}
\hline & $\begin{array}{c}\text { Low County } \\
\text { Population } \\
\text { Density } \\
\end{array}$ & $\begin{array}{c}\text { High County } \\
\text { Population } \\
\text { Density } \\
\end{array}$ & $\begin{array}{c}\text { Non-MSA } \\
\text { Resident During } \\
\text { Adolescence } \\
\end{array}$ & $\begin{array}{c}\text { MSA Resident } \\
\text { During } \\
\text { Adolescence } \\
\end{array}$ & $\begin{array}{c}\text { Low County } \\
\text { Unemployment } \\
\text { Rate } \\
\end{array}$ & $\begin{array}{c}\text { Moderate } \\
\text { County } \\
\text { Unemployment } \\
\text { Rate } \\
\end{array}$ & $\begin{array}{c}\text { High County } \\
\text { Unemployment } \\
\text { Rate } \\
\end{array}$ \\
\hline Math-Reading Achievement Quartile 2 & $\begin{array}{c}0.2738 \\
(0.0281)\end{array}$ & $\begin{array}{c}0.2427 \\
(0.0312)\end{array}$ & $\begin{array}{c}0.2394 \\
(0.0455)\end{array}$ & $\begin{array}{c}0.2553 \\
(0.0229)\end{array}$ & $\begin{array}{c}0.2782 \\
(0.0373)\end{array}$ & $\begin{array}{c}0.2425 \\
(0.0375)\end{array}$ & $\begin{array}{c}0.2547 \\
(0.0344)\end{array}$ \\
\hline Math-Reading Achievement Quartile 3 & $\begin{array}{c}0.4292 \\
(0.0294)\end{array}$ & $\begin{array}{c}0.3593 \\
(0.0317)\end{array}$ & $\begin{array}{c}0.4232 \\
(0.0471)\end{array}$ & $\begin{array}{c}0.3788 \\
(0.0237)\end{array}$ & $\begin{array}{c}0.4150 \\
(0.0375)\end{array}$ & $\begin{array}{c}0.3209 \\
(0.0384)\end{array}$ & $\begin{array}{c}0.4564 \\
(0.0369)\end{array}$ \\
\hline Math-Reading Achievement Quartile 4 & $\begin{array}{c}0.5516 \\
(0.0309)\end{array}$ & $\begin{array}{c}0.4842 \\
(0.0323)\end{array}$ & $\begin{array}{c}0.5610 \\
(0.0505)\end{array}$ & $\begin{array}{c}0.5093 \\
(0.0244)\end{array}$ & $\begin{array}{c}0.5268 \\
(0.0377)\end{array}$ & $\begin{array}{c}0.4786 \\
(0.0404)\end{array}$ & $\begin{array}{c}0.5537 \\
(0.0388)\end{array}$ \\
\hline Parental Income Quartile 2 & $\begin{array}{c}0.0162 \\
(0.0289)\end{array}$ & $\begin{array}{c}0.0598 \\
(0.0338)\end{array}$ & $\begin{array}{c}0.0069 \\
(0.0461)\end{array}$ & $\begin{array}{c}0.0328 \\
(0.0243)\end{array}$ & $\begin{array}{c}0.0738 \\
(0.0389)\end{array}$ & $\begin{array}{c}0.0278 \\
(0.0401)\end{array}$ & $\begin{array}{c}0.0000 \\
(0.0357)\end{array}$ \\
\hline Parental Income Quartile 3 & $\begin{array}{c}0.1267 \\
(0.0309)\end{array}$ & $\begin{array}{c}0.1263 \\
(0.0362)\end{array}$ & $\begin{array}{c}0.1294 \\
(0.0496)\end{array}$ & $\begin{array}{c}0.1174 \\
(0.0257)\end{array}$ & $\begin{array}{c}0.1252 \\
(0.0407)\end{array}$ & $\begin{array}{c}0.1327 \\
(0.0441)\end{array}$ & $\begin{array}{c}0.1380 \\
(0.0379)\end{array}$ \\
\hline Parental Income Quartile 4 & $\begin{array}{c}0.1837 \\
(0.0348)\end{array}$ & $\begin{array}{c}0.1667 \\
(0.0376)\end{array}$ & $\begin{array}{c}0.2301 \\
(0.0578)\end{array}$ & $\begin{array}{c}0.1617 \\
(0.0274)\end{array}$ & $\begin{array}{c}0.1927 \\
(0.0438)\end{array}$ & $\begin{array}{c}0.1611 \\
(0.0469)\end{array}$ & $\begin{array}{c}0.1758 \\
(0.0424)\end{array}$ \\
\hline $\begin{array}{l}\text { Test of no Income Effects (P-value) } \\
\text { Sample Size }\end{array}$ & $\begin{array}{l}<.0001 \\
2,059\end{array}$ & $\begin{array}{l}<.0001 \\
1,724\end{array}$ & $\begin{array}{c}<.0001 \\
807\end{array}$ & $\begin{array}{c}<.0001 \\
3,005\end{array}$ & $\begin{array}{c}0.0001 \\
1,336 \\
\end{array}$ & $\begin{array}{c}0.0007 \\
1,252 \\
\end{array}$ & $\begin{array}{c}<.0001 \\
1,195\end{array}$ \\
\hline
\end{tabular}

Notes: Regressions control for gender, race/ethnicity, immigrant status, whether at least one parent is an immigrant, mother's education (HS graduate, PS attendance), intact family during adolescence, number of children under 18, mother's age at child's birth, metropolitan area during adolescence, and year of birth. Regressions in columns (i), (ii), and (v)-(vii) also control for county of residence and MSA status fixed effects. The dependent variable for all specifications is PS attendance measured as of age 21. Columns (i) and (ii) divide the sample among individuals who at age 15 resided in a county with population density below or above the sample median. Columns (iii) and (iv) divide the sample among individuals who at age 15 resided in our out of a metropolitan statistical area. Columns (v) to (vii) divide the sample among individuals living in a county (based on county of residence at age 15) with unemployment rates in the lowest, middle, or highest terciles in 2000 and 2006. County population and unemployment rates are averaged over years 2000 and 2006 and are obtained from the 2007 County and City Data Book. Test of no Income Effects is an F-test (3 d.o.f.) that all three coefficients on family income are zero. Standard errors are in parentheses. 


\section{Appendix B Post-Secondary Education Finance}

\section{B.1 Non-Repayable Financial Aid in Canada and the U.S.}

Non-repayable aid in the U.S. is distributed by the federal government (mostly as Pell grants and the Supplemental Educational Opportunity Grant), state governments, and institutions themselves. Education tax credits (and deductions) are an additional source of non-repayable aid to students. The NPSAS04 imputes federal Hope and Lifetime Learning tax credits as well as any education deductions based on reported parental income and documents by the Internal Revenue Service reporting education tax credits claimed by income. ${ }^{60}$ For students living away from home, Figure B1 shows averages for each of these sources of non-repayable aid by parental income. $^{61}$

We disaggregate non-repayable aid in Canada differently, since federal aid is exclusively in the form of loans and we do not have measures of institutional support. Figure B2 reports separate amounts (by parental income) for the following categories of non-repayable aid in British Columbia, Ontario, and Quebec: (i) Millennium and provincial grants and bursaries, (ii) loan remissions, and (iii) tax credits. Federal and provincial rules are used to calculate all aid figures as discussed in Appendix D (available online). To the extent that some Canadians do not take advantage of all available tax credits, these figures may be slightly inflated. Because British Columbia does not use loan remissions, the figure only reports remissions for Ontario and Quebec.

\section{B.2 Bounding Net Tuition by Parental Income in the U.S.}

We have used the NPSAS04 to calculate average tuition $T$, financial aid $F$, and net tuition $N T=T-F$ by parental income $I$ conditional on college enrollment; however, we would like unconditional averages for the full population. Here, we calculate bounds on unconditional averages based on assumptions about non-repayable institutional and state aid.

Define a college enrollment indicator, $C \in\{0,1\}$, and $\pi(I)$ the probability someone with parental income $I$ is enrolled in college. Then,

$$
E(N T \mid I)=E(N T \mid I, C=1)-\{\Delta T(I)-[E(F \mid I, C=1)-E(F \mid I, C=0)]\}[1-\pi(I)],
$$

where $\Delta T(I) \equiv E(T \mid I, C=1)-E(T \mid I, C=0)$. In the text, we report estimates of $E(N T \mid I, C=1)$ and $E(F \mid I, C=1)$ using the NPSAS04. Using the NLSY97, it is straightforward to estimate both $\pi(I)$ and $\Delta T(I) \cdot{ }^{62}$

It is not possible to determine $E(F \mid I, C=0)$ from either the NLSY97 or NPSAS04; however, we can bound $E(F \mid I, C=1)-E(F \mid I, C=0)$ using data from NPSAS04. In general, federal student aid offers should be independent of enrolment choices conditional on family income. ${ }^{63}$ In this case, a conservative upper bound on

\footnotetext{
${ }^{60}$ In 2003-04, the federal Hope tax credit was available to first and second year students enrolled at least half-time; it provided full credit on the first $\$ 1,000$ in tuition and fees and a $50 \%$ credit on the next $\$ 1,000$ for a maximum credit of $\$ 1,500$. The Federal Lifetime Learning tax credit, available to all students, provided a credit equal to $20 \%$ of tuition and fees up to a maximum credit of $\$ 2,000$.

${ }^{61}$ We use the same NPSAS04 sample as used in the paper (i.e. 18-24 year-old dependent students that were enrolled in-state in a public four-year PS institution and applied for federal financial aid).

${ }^{62}$ Ignoring any within state variation in in-state tuition at public four-year institutions, $E(T \mid I, C)$ can be estimated with the NLSY97 by assigning average in-state tuition levels to individuals according to their state of residence during adolescence.

${ }^{63}$ To the extent that tuition levels differ across states, it is possible that student need and federal aid differ across states. Given different enrollment rates across states, this could lead to differences in average federal aid by enrollment status. However, since federal aid rarely covers total schooling costs for those eligible, any differences across states (and, therefore, enrollment status) are likely to be very small.
} 
financial aid differences by enrollment status assumes that students who do not enroll in college receive zero state and institutional aid offers. This implies a conservative upper bound (Bound 1) for average net tuition by parental income:

$$
E(N T \mid I) \leq E(N T \mid I, C=1)-\{\Delta T(I)-E(s+i \mid I, C=1)\}[1-\pi(I)]
$$

where $s$ denotes state-based financial aid and $i$ denotes institutional financial aid. If we assume that both state and federal aid are independent of enrollment status (conditional on family income) and that youth not attending PS school receive zero institutional aid, we obtain a sharper upper bound (Bound 2):

$$
E(N T \mid I) \leq E(N T \mid I, C=1)-\{\Delta T(I)-E(i \mid I, C=1)\}[1-\pi(I)] .
$$

Estimates for $E(s \mid I, C=1)$ and $E(i \mid I, C=1)$ can be obtained from the NPSAS04.

Assuming youth choosing not to attend PS school do not receive above average financial aid offers, NPSAS04based estimates of $E(N T \mid I, C=1)$ reported in the paper provide a lower bound on net tuition.

Figures B3 and B4 show these bounds for net tuition and out-of-pocket costs for students living away from home. Given the important role of state-based financial aid, especially in high tuition states, Bound 1 is extremely conservative. Average net tuition and out-of-pocket expenditures almost certainly lie in the narrow region between Bound 2 and the values reported in the text.

\section{Appendix C Counterfactual Non-Repayable Aid Calculations}

In estimating the effects of removing aid and eliminating conditional family income - PS attendance gaps, we disaggregate the population into income categories corresponding to those used in both our spline estimates (see Figures 3a and 3b) and in our financial aid analysis (Figures 4-8). We aggregate over the entire U.S. and over British Columbia, Ontario, and Quebec in Canada.

Based on the literature surveyed in Section 2.2, our calculations assume that each additional $\$ 1,000$ in grant aid increases PS attendance by .03 or .05 for the affected groups. In calculating the effects of eliminating 'conditional' income - attendance gaps, we use the gaps from our spline estimates (see Figures 3a and 3b).

To calculate the effect of removing need-based aid, we multiply the difference in non-repayable aid between each income group and the highest income group (family income over $\$ 100,000$ ), by the effect of non-repayable aid on PS attendance. Letting $E_{j}$ reflect the initial non-repayable aid and $A_{j}$ the initial attendance attendance rate for income group $j$, we compute the counterfactual attendance rate $A_{j}^{\prime}=A_{j}-\gamma\left(E_{j}-E_{\text {top }}\right) / 1000$, where $E_{t o p}$ is the aid given to the top income group and $\gamma$ is 0.03 or 0.05 .

In calculating the additional aid required to eliminate conditional attendance gaps, let $A_{j}$ reflect the current attendance rate for youth in income category $j$ and $A_{j}^{\prime}$ the counterfactual attendance rate associated with no conditional income - attendance gap (determined from the spline estimates shown in Figures $3 \mathrm{a}$ and $3 \mathrm{~b}$ ). Letting $E_{j}$ reflect current non-repayable aid amount, the counterfactual required aid amount is $E_{j}^{\prime}=E_{j}+1000 \times\left(A_{j}^{\prime}-\right.$ $\left.A_{j}\right) / \gamma$ where $\gamma$ is 0.03 or 0.05 . 
Figure B1: Non-Repayable Aid by Source in the US (Students Living Away from Parents)

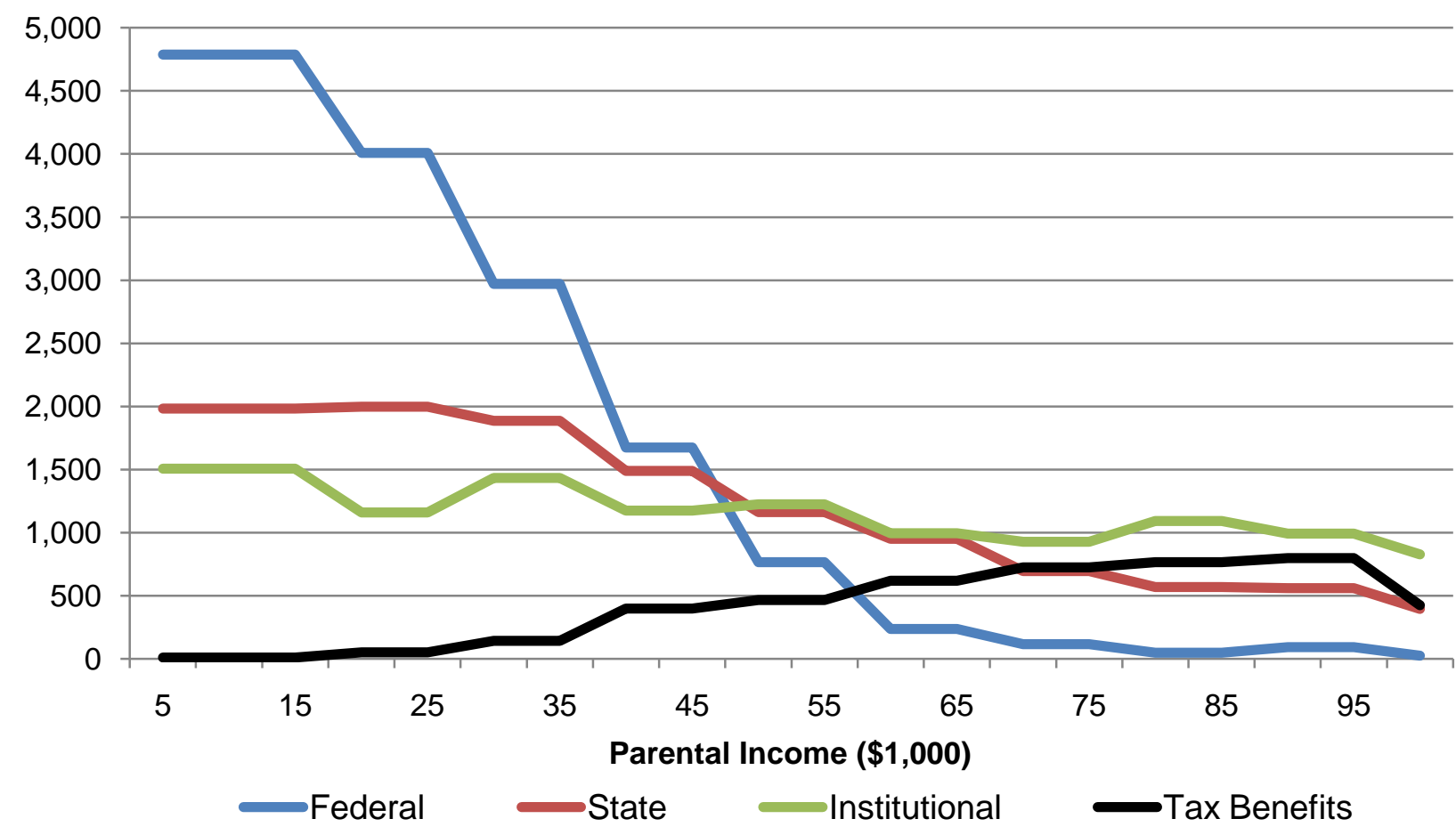

Figure B2: Non-Repayable Aid by Source in Canada (Students Living Away from Parents)

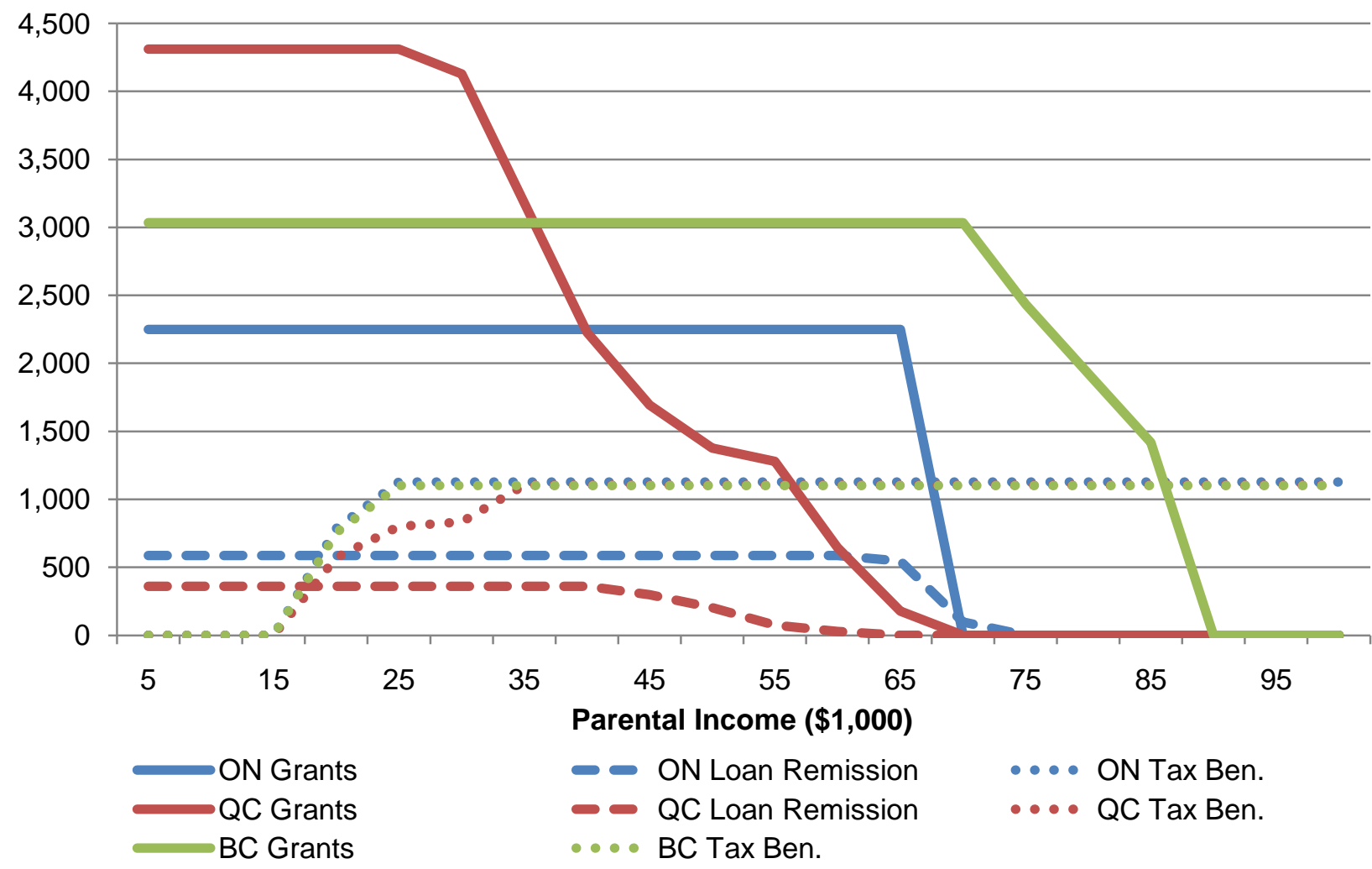


Figure B3: Net Tuition with US Bounds (Students Living Away From Parents)

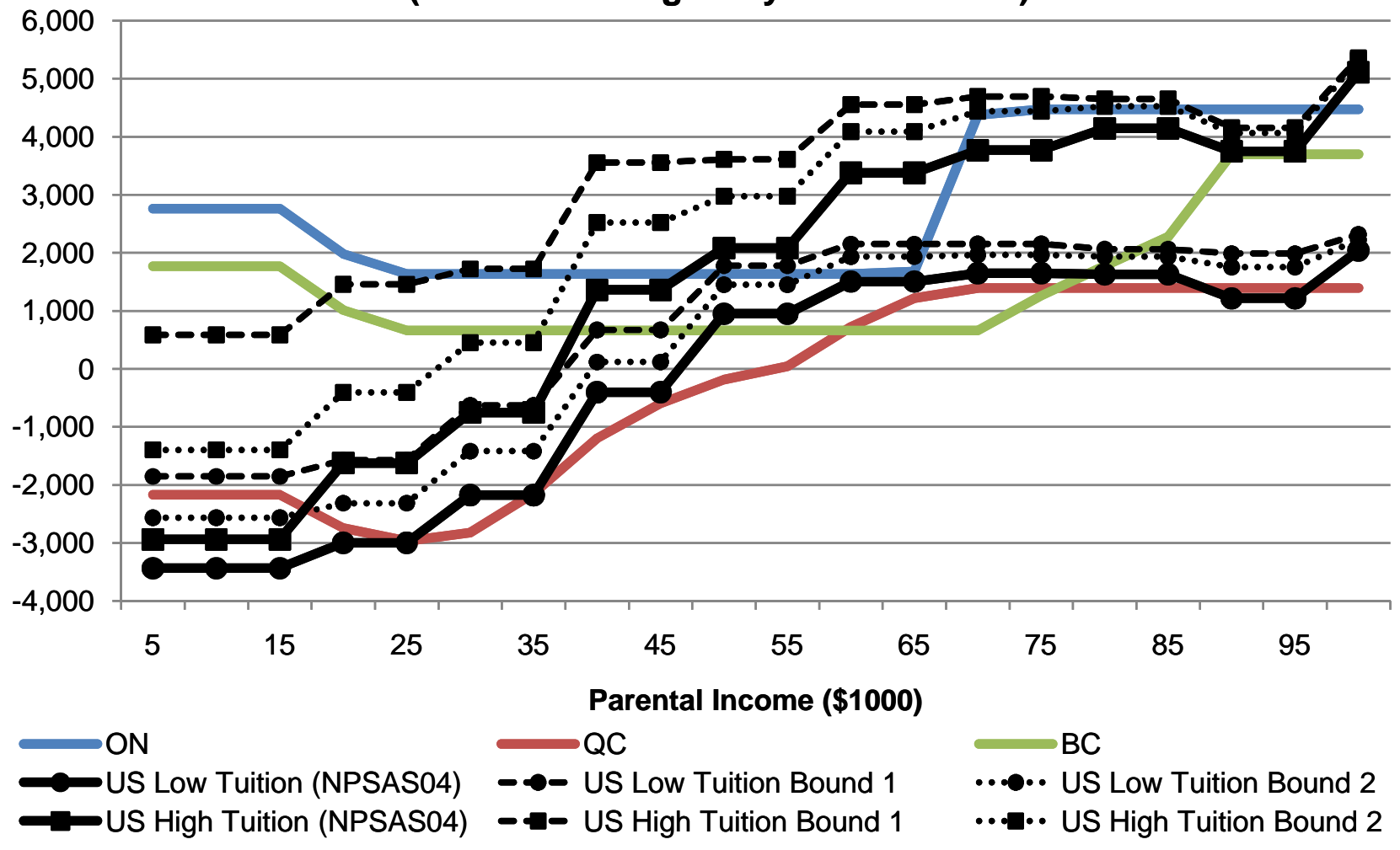

Figure B4: Out-of-Pocket Costs with US Bounds (Students Living Away From Parents)

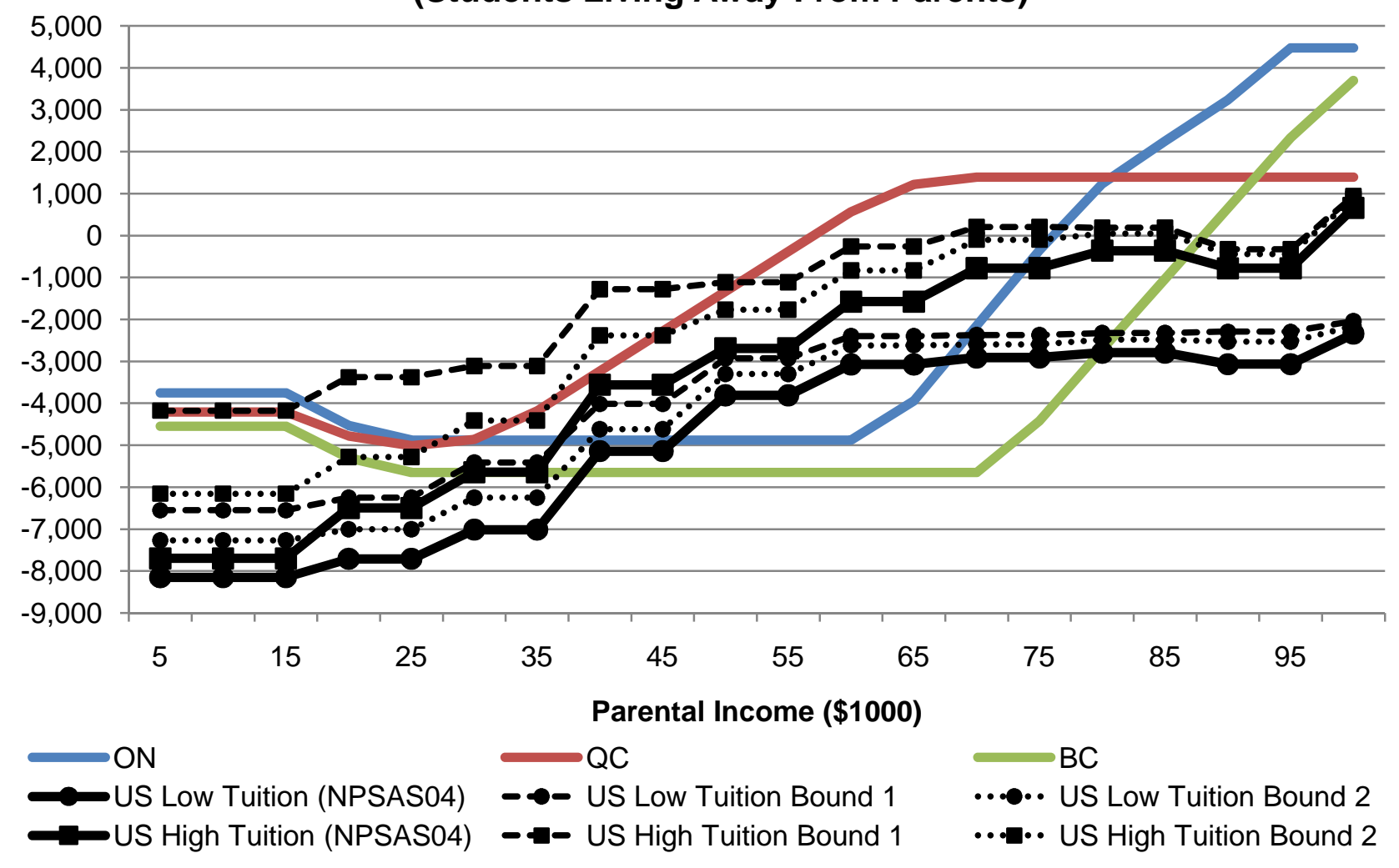

